\title{
PENGARUH LEVERAGE, PERTUMBUHAN PENJUALAN, DAN UKURAN PERUSAHAAN TERHADAP PROFITABILITAS
}

\author{
M. Jamal Abdul Nasir \\ Universitas Gajayana \\ Malang \\ e-mail : jamal@unigamalang.ac.id
}

\begin{abstract}
The purpose of this study was to determine (1) the effect of leverage on profitability, (2) the effect of sales growth on profitability, (3) the effect of company size on profitability. used in this study amounted to 4 companies. The results of this study indicate that leverage has a negative and significant effect on profitability in cigarette companies listed on the IDX during the 2016-2018 period, sales growth has a negative and significant effect on profitability in cigarette companies listed on the IDX during the 2016-2018 period. And also company size has a positive and significant effect on profitability in cigarette companies listed on the IDX during the 2016-2018 period. And each independent variable has a positive and significant effect on the dependent variable simultaneously, namely leverage, sales growth and company size which have a significant effect on profitability in cigarette companies listed on the IDX during the 2016-2018 period. So it can be concluded that each independent variable has a significant influence on the dependent variable either partially or simultaneously.
\end{abstract}

\begin{abstract}
ABSTRAK
Tujuan penelitian ini adalah untuk mengetahui (1) pengaruh leverage terhadap profitabilitas, (2) pengaruh pertumbuhan penjualan terhadap profitabilitas, (3) pengaruh ukuran perusahaan terhadap profitabilitas. Sampel dalam penelitian ini adalah perusahaan perusahaan rokok yang listing di BEI dengan jumlah sampel yang akan digunakan dalam penelitian ini berjumlah 4 perusahaan. Hasil penelitian ini menunjukkan bahwa leverage berpengaruh negatif dan signifikan terhadap profitabilitas pada perusahaan rokok yang terdaftar di BEI selama periode 2016-2018, pertumbuhan penjualan berpengaruh negatif dan signifikan terhadal profitabilitas pada perusahaan rokok yang terdaftar di BEI selama periode 2016-2018. Dan juga ukuran perusahaan memiliki pengaruh positif dan signifikan terhadap profitabilitas pada perusahaan rokok yang terdaftar di BEI selama periode 2016-2018. Dan setiap variabel independen memiliki pengaruh yang positif dan signifikan terhadap variabel dependen secara simultan yaitu leverage, pertumbuhan penjualan dan ukuran perusahaan yang memiliki pengaruh signifikan terhadap profitabilitas pada perusahaan rokok yang terdaftar di BEI selama periode 2016-2018. Jadi dapat diambil kesimpulan bahwa setiap variabel independen memiliki pengaruh yang signifikan terhadap variabel dependen baik secara parsial maupun secara simultan.
\end{abstract}

Kata Kunci : Leverage, Pertumbuhan penjualan, Ukuran perusahaan, Profitabilitas.

\section{PENDAHULUAN}

Di era globalisasi sekarang ini perusahaan berkembang seperti Indonesia di tuntut untuk terus memperbaiki perekonomian. Melalui Menteri Koordinator Perekonomian pemerintah ingin menyampaikan bahwa pemerintah ingin menjadikan sektor industri 


\section{Buletin Ekonomi}

manufaktur sebagai tulang punggung perekonomian. Hal ini disebabkan karena industri manufaktur berperan penting dalam upaya menggenjot nilai investasi dan ekspor sehingga menjadi sektor andalan untuk mempercepat pertumbuhan ekonomi nasional sekaligus sebagai pembuka lapangan kerja yang efektif.

Perusahaan manufaktur merupakan perusahaan yang bergerak di bidang pembuatan produk yang kemudian dijual dengan tujuan memperoleh profit yang besar. Proses manufaktur sendiri berarti proses membuat atau mengubah bahan mentah menjadi barang yang dapat dikonsumsi manusia dengan tangan atau mesin. Industri manufaktur yang terdapat di Bursa Efek Indonesia terbagi atas beberapa sektor yang masing masing mempunyai peran dalam mendukung perkembangan perekonomian Indonesia.

Salah satu industri manufaktur yang cukup signifikan perannya adalah industri rokok yang sekaligus akan dijadikan obyek dalam penelitian ini. Industri rokok telah mengakar ratusan tahun lalu sejak zaman penjajahan yang menyebabkan industri ini menjadi kuat dan besar hingga saat ini. Indonesia merupakan salah satu pasar yang potensial bagi industri rokok saat ini, mengingat jumlah penjualan rokok nasional mengalami kenaikan setiap tahunnya. Industri rokok di tanah air telah memainkan peranan dan dampak perekonomian yang tidak kecil di tengah masyarakat. Peranan industri rokok di Indonesia saat ini terlihat semakin besar, hal ini terlihat dari semakin besarnya penerimaan negara dari cukai dan pajak rokok dari tahun ke tahun.

Dari sudut pandang prinsip ekonomi, suatu perusahaan didirikan dengan tujuan memaksimumkan laba dan meminimumkan biaya, sehingga dapat memperoleh laba yang optimal dan nilai perusahaan yang meningkat. Kondisi perusahaan dapat dijadikan sebagai acuan untuk pengukuran kekuatan dan perkembangan perusahaan dalam mencapai tujuannya. Untuk mencapai hal tersebut perusahaan harus dapat mengelola sumber daya keuangan yang dimilikinya dengan efisien dan efektif.

Salah satu cara untuk mencapai tujuan tersebut adalah dengan meningkatkan profitabilitas perusahaan. Profitabilitas yang tinggi menunjukkan semakin efektif perusahaan dalam menjalankan operasinya, sehingga mampu meningkatkan laba yang optimal. Laba optimal yang diperoleh perusahaan akan mempengaruhi kelangsungan hidup perusahaan tersebut dan menjamin perusahaan dapat terus berkembang mengikuti tantangan zaman.

Untuk mencapai tujuan tersebut, diperlukan manajemen dengan tingkat efektifitas yang tinggi. Untuk mengukur tingkat keuntungan suatu perusahaan, digunakan rasio keuntungan atau rasio profitabilitas, dengan menggunakan perbandingan antara berbagai komponen yang ada di laporan keuangan. Pengukuran rasio profitabilitas dapat digunakan sebagai indikator bagi manajemen untuk memaksimalkan laba yang di dapat perusahaan, dengan demikian manajer keuangan perlu mengetahui faktor-faktor yang berpengaruh besar terhadap profitabilitas perusahaan.

Secara umum, profitabilitas merupakan kemampuan perusahaan dalam menghasilkan laba atau keuntungan. Menurut Munawir (2014:33), profitabilitas adalah kemampuan perusahaan untuk menghasilkan laba selama periode tertentu. Jumlah laba bersih sering dibandingkan dengan ukuran kegiatan atau kondisi keuangan lainnya seperti penjualan, aktiva, dan ekuitas pemegang saham. Profitabilitas dalam penelitian ini diproksikan dengan return on asset (ROA) karena dapat menunjukkan bagaimana kinerja perusahaan dilihat dari penggunaan keseluruhan aset yang dimiliki oleh perusahaan dalam menghasilkan keuntungan. Suatu perusahaan dikatakan baik apabila dapat beroperasi secara stabil dalam jangka panjang, sehingga perusahaan tidak akan mengalami kesulitan mengembalikan hutang-hutangnya baik jangka panjang maupun jangka pendek.

Leverage merupakan jumlah utang yang digunakan untuk membiayai/membeli asetaset perusahaan. Hutang (leverage) adalah salah satu faktor penting yang mempengaruhi 


\section{Buletin Ekonomi}

profitabilitas karena bisa digunakan perusahaan untuk meningkatkan modal dalam rangka meningkatkan keuntungan. Dengan kata lain, leverage adalah penggunaan assets dan sumber dana oleh perusahaan yang memiliki biaya tetap (beban tetap), dengan tujuan untuk meningkatkan keuntungan pemegang saham. Perusahaan yang akan menggunakan leverage tersebut mempunyai tujuan supaya keuntungan yang akan didapatkan itu lebih besar dari biaya tetap (beban tetap).

Perusahaan memperoleh sumber dana dari dalam perusahaan dan luar perusahaan, sumber dana dari dalam perusahaan berupa penyusutan dan laba ditahan, sedangkan sumber dana dari luar perusahaan berupa hutang dan penerbitan saham. Leverage adalah salah satu faktor penting yang mempengaruhi profitabilitas karena dapat meningkatkan modal perusahaan dengan tujuan meningkatkan keuntungan. Karena meskipun hutang dapat meningkatkan produktivitas, tetapi diperlukan pengelolaan yang baik, jika perusahaan menggunakan lebih banyak hutang dari pada modal sendiri maka tingkat solvabilitas akan menurun, sehingga beban bunga yang harus ditanggung juga meningkat. Hal ini akan berdampak terhadap menurunnya profitabilitas. Apabila proporsi leverage di abaikan oleh perusahaan maka akan mengakibatkan turunnya profitabilitas, karena penggunaan hutang menimbulkan beban bunga yang bersifat tetap. Menurut Fahmi (2015:72) leverage adalah ukuran seberapa besar perusahaan dibiayai dengan utang. Penggunaan utang yang terlalu tinggi akan membahayakan perusahaan karena perusahaan akan masuk dalam kategori extreme leverage (utang ekstrim) yaitu perusahaan terjebak dalam tingkat utang yang tinggi dan sulit untuk melepaskan beban utang tersebut. Tetapi, leverage juga dianggap dapat membantu perusahaan untuk menyelamatkan perusahaan dalam kegagalan apabila digunakan secara efektif, namun juga dapat menyebabkan kebangkrutan bagi perusahaan apabila dikelola dengan cara sebaliknya karena perusahaan kesulitan dalam membayar hutang-hutang tersebut.

Secara umum dapat dijelaskan bahwa penggunaan utang yang relatif tinggi akan menimbulkan biaya tetap berupa beban bunga dan angsuran pokok pinjaman yang harus dibayar. Semakin besar biaya tetap dapat berakibat menurunnya laba perusahaan. Dengan demikian perusahaan yang mendanai assetnya dengan hutang, profitabilitasnya akan menurun karena perusahaan harus memenuhi beban yang harus dibayar dari penggunaan hutang tersebut (bunga). Selain itu, perusahaan memiliki risiko keuangan yang tinggi karena perusahaan terlalu banyak melakukan pendanaan asetnya dari hutang. Seperti adanya risiko gagal bayar, maka biaya yang harus dikeluarkan oleh perusahaan untuk mengatasi masalah ini semakin besar.

Penjualan merupakan kriteria penting untuk menilai profitabilitas perusahaan dan merupakan indikator utama atas aktivitas perusahaan. Pertumbuhan penjualan merupakan ukuran paling tepat mengenai kondisi kestabilan keuangan suatu perusahaan. Pertumbuhan Penjualan juga menggambarkan kemampuan perusahaan dalam mempertahankan posisi ekonominya di tengah pertumbuhan perekonomian pada sektor usahanya. Pertumbuhan penjualan merupakan perubahan kenaikan ataupun penurunan penjualan dari tahun ke tahun yang dapat dilihat pada laporan laba-rugi perusahaan. Perusahaan dengan penjualan yang relatif stabil dapat memperoleh lebih banyak pinjaman dibanding dengan perusahaan yang penjualannya tidak stabil. Salah satu faktor penting mengenai kelangsungan hidup perusahaan adalah penjualan. Manajer perusahaan harus dapat meningkatkan penjualan produk, karena tingkat pertumbuhan penjualan yang sangat tinggi akan meningkatkan volume penjualan. Dengan kata lain, kapasitas produksi perlu ditingkatkan. Peningkatan kapasitas produksi tersebut akan memerlukan sumber dana yang tidak sedikit. Sehingga perusahaan akan cenderung menggunakan hutang dengan tujuan tingkat volume produksi yang meningkat dapat mengimbangi tingkat penjualan yang tinggi. Perusahaan dengan penjualan 


\section{Buletin Ekonomi}

yang tidak stabil maka tidak dapat menggunakan hutang yang besar, sedangkan perusahaan dengan aliran kas yang relatif stabil dapat menggunakan hutang lebih banyak.

Menurut Ernawati (2016) ukuran perusahaan menggambarkan besar kecilnya suatu perusahaan yang dapat dinyatakan dengan total aset atau total penjualan bersih. Perusahaan yang memiliki ukuran lebih besar memiliki dorongan yang kuat untuk menghasilkan tingkat profitabilitas yang tinggi dibandingkan dengan perusahaan yang lebih kecil. Selain itu, perusahaan dangan ukuran yang lebih besar memiliki akses yang lebih besar untuk mendapat sumber pendanaan dari berbagai sumber, sehingga untuk memperoleh pinjaman dari kreditur akan lebih mudah karena perusahaan dengan ukuran besar memiliki profitabilitas lebih besar untuk memenangkan persaingan atau bertahan dalam industry. Pada sisi lain, meskipun perusahaan kecil (UKM) tidak memiliki akses terhadap pendanaan pihak ke-3 sebaik perusahaan besar, tetapi perusahaan dengan skala kecil lebih fleksibel dalam menghadapi ketidakpastian, karena perusahaan kecil lebih cepat bereaksi terhadap perubahan mendadak. Oleh karena itu, memungkinkan perusahaan besar tingkat leverage-nya lebih besar dari perusahaan kecil.

Ukuran perusahaan dapat dilihat dari total aset, total penjualan, jumlah karyawan, dan kapitalisasi pasar. Penentuan ukuran perusahaan dalam penelitian ini didasarkan kepada total aset perusahaan, karena total aset dianggap lebih stabil dan lebih dapat mencerminkan ukuran perusahaan (Nurminda 2017). Dalam artian semakin besar aktiva suatu perusahaan maka akan semakin besar pula modal yang ditanam. Semakin besar total penjualan suatu perusahaan maka akan semakin banyak juga perputaran uang dan semakin besar kapitalisasi pasar maka semakin besar pula perusahaan dikenal oleh masyarakat. Pertumbuhan perusahaan berbanding Lurus dengan Ukuran perusahaan, sehingga semakin cepat pertumbuhan perusahaan maka semakin besar pula ukuran perusahaan.

Berdasarkan latar belakang masalah di atas, maka tujuan dari penelitian ini antara lain: Menganalisis pengaruh laverage, pertumbuhan penjualan, dan ukuran perusahaan terhadap profitabilitas pada perusahaan rokok yang terdaftar di Bursa Efek Indonesia.

Berdasarkan latar belakang yang telah dikemukakan, maka dalam penelitian ini rumusan masalah yang dapat diidentifikasi adalah apakah leverage, pertumbuhan penjualan, dan ukuran perusahaan berpengaruh secara parsial dan simultan terhadap profitabilitas pada perusahaan rokok yang terdapat di Bursa Efek Indonesia?

Berdasarkan permasalahan penelitian yang telah dirumuskan, maka tujuan dari penelitian ini adalah untuk menguji pengaruh leverage, pertumbuhan penjualan, dan ukuran perusahaan terhadap profitabilitas pada perusahaan rokok yang terdapat di Bursa Efek Indonesia.Menguji pengaruh leverage terhadap profitabilitas pada perusahaan rokok yang terdapat di Bursa Efek Indonesia.Untuk menguji pengaruh pertumbuhan penjualan terhadap profitabilitas pada perusahaan rokok yang terdapat di Bursa Efek Indonesia.

Untuk menguji pengaruh ukuran perusahaan terhadap profitabilitas pada perusahaan rokok yang terdapat di Bursa Efek Indonesia.

Manfaat dalam penelitian ini adalah diharapkan memberikan manfaat teoritis, yaitu sebagai tambahan referensi untuk mengembangkan ilmu pengetahuan khususnya bidang manajemen keuangan. Serta manfaat praktis, yaitu memberikan informasi akan pengaruh leverage, pertumbuhan penjualan dan ukuran perusahaan terhadap profitabilitas.

\section{Leverage}

Menurut Maryam (2014), leverage adalah penggunaan sejumlah aset atau dana oleh perusahaan dimana dalam penggunaan aset atau dana tersebut, perusahaan harus mengeluarkan biaya tetap. Dengan kata lain seberapa besar perusahaan membiayai asetnya 


\section{Buletin Ekonomi}

dengan utang. Penggunaan utang yang terlalu tinggi akan membahayakan perusahaan karena perusahaan akan masuk dalam kategori extreame leverage (utang ekstrim) yaitu perusahaan terjebak dalam tingkat utang yang tinggi dan sulit untuk melepaskan beban utang tersebut (Fahmi,2015 dalam Hantono, 2017). Leverage juga dianggap dapat membantu perusahaan untuk menyelamatkan perusahaan dalam kegagalan apabila digunakan secara efektif, namun juga dapat menyebabkan kebangkrutan bagi perusahaan apabila dikelola dengan cara sebaliknya karena perusahaan kesulitan dalam membayar hutang-hutangnya tersebut. Karena itu sebaiknya perusahaan harus menyeimbangkan berapa utang yang layak diambil dan dari mana sumber-sumber yang dapat dipakai untuk membayar utang.

Leverage dipergunakan untuk menggambarkan kemampuan perusahaan untuk menggunakan aktiva atau dana yang mempunyai beban tetap (fixed cost assets or funds) untuk memperbesar tingkat penghasilan (return) bagi pemilik perusahaan. Selain itu laverage digunakan untuk mengukur kemampuan perusahaan untuk membayar seluruh kewajibannya, baik jangka pendek maupun jangka panjang apabila perusahaan dibubarkan (Kasmir, 2017:151).

Leverage adalah salah satu faktor penting yang mempengaruhi profitabilitas karena dapat meningkatkan modal perusahaan dengan tujuan meningkatkan keuntungan. Leverage timbul karena perusahaan dalam operasinya menggunakan aktiva dan sumber dana yang menimbulkan beban tetap, yang berupa biaya penyusutan dari aktiva tetap, dan biaya bunga dari hutang. Perusahaan yang akan menggunakan leverage tersebut mempunyai tujuan supaya keuntungan yang akan didapatkan itu lebih besar dari biaya tetap (beban tetap). Fakhrudin dalam Satriana (2017:23) memberikan definisi bahwa leverage merupakan jumlah utang yang dipergunakan untuk membiayai/membeli aset-aset perusahaan. Perusahaan dengan tingkat laverage yang lebih besar daripada ekuitas atau modal senditi dapat dikatakan sebagai perusahaan dengan tingkat leverage yang tinggi.

Rasio Leverage menurut Kasmir (2015:151) merupakan rasio yang digunakan dalam mengukur sejauh mana aktiva perusahaan dibiayai dengan utang. Artinya berapa besar beban utang yang ditanggung perusahaan dibandingkan dengan aktivanya. Dalam arti luas dikatakan bahwa rasio solvabilitas digunakan untuk mengukur kemampuan perusahaan untuk membayar seluruh kewajibannya, baik jangka pendek maupun jangka panjang apabila perushaaan dibubarkan (dilikuidasi). Rasio leverage menggambarkan hubungan antara utang perusahaan terhadap modal, rasio ini dapat melihat seberapa jauh perusahaan dibiayai oleh utang atau pihak luar dengan kemampuan perusahaan yang digambarkan oleh modal. Rasio ini digunakan untuk membandingkan sumber modal yang berasal dari hutang (hutang jangka panjang dan hutang jangka pendek) dengan modal sendiri. Hal ini biasanya digunakan untuk mengukur financial leverage dari suatu perusahaan. Indikator rasio leverage dalam penelitian ini diproksikan dengan Debt to Assets Ratio (DAR)

\section{Debt to Asset Ratio (DAR)}

Debt to Assets Ratio (Debt Ratio) menurut Kasmir (2016: 156) adalah rasio utang yang digunakan untuk mengukur perbandingan antara total utang dengan total aktiva. Dengan kata lain, seberapa besar aktiva perusahaan dibiayai oleh utang atau seberapa besar utang perusahaan berpengaruh terhadap pengelolaan aktiva. Selain itu Debt to Asset Ratio merupakan salah satu rasio yang digunakan untuk mengukur Tingkat solvabilitas perusahaan dalam mengukur kemampuan perusahaan untuk membayar kewajiban jangka panjang perusahaan tersebut. Suatu perusahaan dikatakan solvabel berarti perusahaan tersebut memiliki aktiva dan kekayaan yang cukup untuk membayar hutang-hutangnya.

Rasio ini menunjukkan besarnya total hutang terhadap keseluruhan total aktiva yang dimiliki oleh perusahaan. Rasio hutang juga merupakan komposisi dana yang diberikan oleh kreditor kepada perusahaan. Rasio hutang bisa berarti buruk, pada situasi ekonomi sulit dan 


\section{Buletin Ekonomi}

suku bunga tinggi, hal ini menyebabkan perusahaan yang memiliki rasio hutang tinggi dapat mengalami masalah keuangan. Namun selama ekonomi baik dan suku bunga rendah maka dapat meningkatkan keuntungan. Nilai rasio yang tinggi menunjukkan peningkatan resiko pada kreditor berupa ketidakmampuan perusahaan membayar semua kewajibannya.

Debt to Asset Ratio digunakan untuk mengukur seberapa besar jumlah aktiva perusahaan dibiayai dengan hutang atau berapa besar hutang perusahaan berpengaruh terhadap pengelolaan aktiva. Semakin tinggi nilai DAR berarti semakin besar sumber dana melalui pinjaman untuk membiayai aktiva. Nilai DAR yang tinggi menunjukkan risiko yang tinggi pula karena ada kekhawatiran perusahaan tidak mampu menutupi hutang-hutangnya dengan aktiva yang dimiliki, yang menyebabkan perusahaan kesulitan memperoleh tambahan pinjaman. Rumus yang digunakan adalah sebagai berikut :

$$
D A R=\frac{\text { Total Kewajiban }}{\text { total aktiva }}
$$

\section{Pertumbuhan Penjualan}

Menurut Kasmir dalam Putri (2015) pertumbuhan penjualan merupakan gambaran atas kemampuan perusahaan dalam mempertahankan posisi ekonominya di tengah pertumbuhan perekonomian dan sektor usahanya. Menurut Swastha dan Handoko dalam Farhana,dkk (2016:4) pertumbuhan penjualan merupakan indikator penting dari penerimaan pasar dari produk dan atau jasa perusahaan tersebut, dimana pendapatan yang dihasilkan dari penjualan akan dapat digunakan untuk mengukur tingkat pertumbuhan penjualan. Pertumbuhan penjualan merupakan indikator maju atau tidaknya suatu perusahaan karena merupakan perubahan penjualan yang ada pada laporan keuangan per tahun. Suatu perusahaan yang berada dalam industri yang mempunyai laju pertumbuhan tinggi harus menyediakan modal cukup besar untuk pendanaannya. Perusahaan yang pertumbuhannya pesat cenderung lebih banyak menggunakan hutang dari pada perusahaan yang pertumbuhannya lambat.

Pertumbuhan Penjualan adalah kenaikan jumlah penjualan dari tahun ke tahun atau dari waktu ke waktu. Pertumbuhan penjualan merupakan salah satu faktor yang penting dalam penetapan struktur modal perusahaan karena dengan meningkatnya tingkat penjualan perusahaan maka laba dan pendapatan yang akan didapat oleh perusahaan juga akan meningkat. Selain itu, meningkatnya pertumbuhan penjualan juga akan dapat meningkatkan nilai perusahaan. Pertumbuhan penjualan memiliki pengaruh yang positif terhadap struktur modal dan strategi perusahaan karena penjualan yang dilakukan harus didukung dengan harta atau aset. Jika penjualan ditingkatkan, maka aset pun harus ditambah. Dengan mengetahui penjualan dari tahun sebelumnya, perusahaan dapat mengoptimalkan sumber daya yang ada. Suatu perusahaan dengan tingkat pertumbuhan yang rendah tidak membutuhkan biaya eksternal, tetapi perusahaan yang tumbuh dengan pesat memerlukan modal dari sumber eksternal. Semakin cepat tingkat pertumbuhan semakin besar pula kebutuhan modal, sehingga perusahaan dengan pertumbuhan akan lebih aman memperoleh pinjaman dari pada perusahaan yang pertumbuhannya tidak stabil. Menurut Weston dan Brigham dalam Farhana,dkk (2016:5) dengan mengetahui seberapa besar pertumbuhan penjualan, perusahaan dapat memprediksi seberapa besar profit yang akan diperoleh. Untuk mengukur pertumbuhan penjualan dapat dihitung dengan penjualan sekarang dikurangi dengan penjualan tahun sebelumnya dibagi penjualan tahun sebelumnya dikali seratus persen. Jika persentase perbandingan semakin besar maka dapat disimpulkan bahwa pertumbuhan penjualan semakin baik atau lebih baik dari periode tahun sebelumnya. Rumus yang digunakan adalah sebagai berikut : 


\section{Buletin Ekonomi}

$$
\text { Pertumbuhan Penjualan }=\frac{\text { Penjualan tahun ini }- \text { Penjualan tahun lalu }}{\text { Penjualan tahun lalu }} \times 100 \%
$$

\section{Ukuran Perusahaan}

Menurut Ernawati (2016) ukuran perusahaan menggambarkan besar kecilnya suatu perusahaan yang dapat dinyatakan dengan total aset atau total penjualan bersih. Ukuran perusahaan merupakan suatu skala dimana dapat diklasifikasikan besar kecilnya perusahaan. Ukuran perusahaan merupakan salah satu indikator yang digunakan investor dalam menilai asset maupun kinerja perusahaan. Menurut Rudangga dan Sudiarta (2016) Ukuran perusahaan dapat dinyatakan dengan total asset yang dimiliki oleh perusahaan. Dalam ukuran perusahaan terdapat tiga variabel yang dapat menentukan ukuran perusahaan yaitu total asset, penjualan, dan kapitalisasi pasar. Karena variabel itu dapat menentukan besarnya suatu perusahaan. Penentuan ukuran perusahaan dalam penelitian ini didasarkan kepada total aset perusahaan, karena total aset dianggap lebih stabil dan lebih dapat mencerminkan ukuran perusahaan (Nurminda 2017). Semakin tinggi total asset (yang menunjukkan harta yang dimiliki perusahaan) mengindikasikan bahwa perusahaan tersebut tergolong perusahaan besar. Sebaliknya, semakin rendah total asset mengindikasikan bahwa perusahaan tersebut tergolong perusahaan kecil. Semakin besar total asset menunjukkan bahwa semakin besar pula harta yang dimiliki perusahaan, sehingga investor akan semakin aman dalam berinvestasi ke perusahaan tersebut.

Ukuran perusahaan yang didasarkan pada total assets yang dimiliki oleh perusahaan diatur dengan ketentuan Menteri Koperasi dan Usaha Kecil dan Menengah 06/per/M.KUKM/XI/2012 menurut Undang-Undang No.20 Tahun 2008 Berdasarkan uraian di atas, maka untuk menentukan ukuran perusahaan digunakan ukuran aktiva. Perusahaan yang mempunyai aset lebih besar cenderung memiliki kemampuan bersaing yang lebih baik dibandingkan dengan perusahaan-perusahaan yang memiliki aset kecil. Dalam artian semakin besar aktiva suatu perusahaan maka akan semakin besar pula modal yang ditanam. Semakin besar total penjualan suatu perusahaan maka akan semakin banyak juga perputaran uang dan semakin besar kapitalisasi pasar maka semakin besar pula perusahaan dikenal oleh masyarakat. Pertumbuhan perusahaan berbanding Lurus dengan Ukuran perusahaan, sehingga semakin cepat pertumbuhan perusahaan maka semakin besar pula ukuran perusahaan.

Perusahaan yang lebih besar memiliki akses yang lebih besar untuk mendapat sumber pendanaan dari berbagai sumber sehingga untuk memperoleh pinjaman dari kreditur pun akan lebih mudah karena perusahaan dengan ukuran besar memiliki profitabilitas lebih besar untuk memenangkan persaingan atau bertahan dalam industri. Semakin besar ukuran suatu perusahaan, maka kecenderungan menggunakan modal asing juga semakin besar. Hal ini disebabkan karena perusahaan besar membutuhkan dana yang besar pula untuk menunjang operasionalnya, dan salah satu alternatif pemenuhannya adalah dengan modal asing apabila modal sendiri tidak mencukupi.

Size juga dapat digunakan sebagai proksi untuk menjelaskan berbagai pengungkapan laporan tahunan terkait informasi internal perusahaan. Penelitian yang dilakukan oleh Utari (2014) memiliki hasil bahwa ukuran perusahaan berpengaruh positif signifikan terhadap profitabilitas. Ukuran perusahaan diproksikan dengan total aktiva perusahaan setiap tahun. Hal ini menunjukkan seberapa besar harta yang dimiliki perusahaan. Perusahaan dengan asset yang besar cenderung akan menggunakan sumber daya yang ada semaksimal mungkin untuk menghasilkan keuntungan usaha yang maksimal. Perusahaan dengan asset yang kecil 


\section{Buletin Ekonomi}

tentunya juga menghasilkan keuntungan sesuai dengan asset yang dimilikinya yang relatif kecil

Ukuran Perusahaan menunjukkan besar atau kecilnya kekayaan (asset) yang dimiliki suatu perusahaan. Pengukuran ini bertujuan untuk membedakan secara kuantitatif antara perusahaan besar (large firm) dengan perusahaan kecil (small firm), perbedaan besar kecilnya suatu perusahaan dapat mempengaruhi kemampuan manajemen untuk mengoperasikan perusahaan dengan berbagai situasi dan kondisi yang dihadapinya. Pengukuran aktiva dapat diukur dengan logaritma dari total aktiva. Logaritma digunakan untuk memperhalus asset karena nilai dari asset tersebut yang sangat besar dibanding variabel keuangan lainnya. Rumus yang digunakan adalah sebagai berikut :

$$
\text { Size }=\log \text { Total Asset }
$$

\section{Profitabilitas}

Menurut Kasmir (2015:110) profitabilitas merupakan rasio untuk menilai kemampuan perusahaan dalam mencari keuntungan atau laba dalam suatu periode tertentu. Menurut Sartono dalam Fatmawati (2017:19) profitabilitas adalah kemampuan perusahaan dalam memperoleh laba dalam hubungannya dengan penjualan, total aktiva, maupun modal sendiri. Tinggi rendahnya laba merupakan faktor penting perusahaan. Besar kecilnya laba perusahaan dapat diketahui melalui analisa laporan keuangan perusahaan dengan rasio profitabilitas. Salah satu cara memperoleh informasi yang bermanfaat dari laporan keuangan perusahaan adalah dengan melakukan analisis rasio keuangan, salah satunya adalah rasio profitabilitas. Rasio Profitabilitas merupakan perbandingan antara laba dengan aktiva atau modal yang menghasilkan laba tersebut dan dinyatakan dalam persentase. Dapat di jelaskan, karena pengertian profitabilitas sering digunakan untuk mengukur efisiensi penggunaan modal dalam perusahaan, maka rentabilitas ekonomis sering pula dimaksudkan sebagai kemampuan perusahaan dengan seluruh modal yang bekerja di dalamnya untuk menghasilkan laba. Laba yang diraih dari kegiatan yang dilakukan merupakan cerminan sebuah kinerja perusahaan dalam menjalankan usahanya. Menjaga tingkat profitabilitas merupakan hal yang penting bagi perusahaan karena profitabilitas yang tinggi merupakan tujuan setiap perusahaan. Jika dilihat dari perkembangan rasio profitabilitas suatu perusahaan didapati peningkatan, maka hal tersebut menunjukkan kinerja perusahaan yang efisien. Menurut Kasmir (2015:196) "Profitabilitas adalah rasio untuk menilai kemampuan perusahaan dalam mencari keuntungan. Rasio ini juga memberikan ukuran tingkat efektifitas manajemen suatu perusahaan. Hal ini ditunjukan oleh laba yang dihasilkan dari penjualan dan pendapatan investasi. Intinya dalah penggunaan rasio ini menunjukan efisiensi perusahaan". Sedangkan menurut Martono dan Agus Harjito (2014:19) "Profitabilitas adalah kemampuan perusahaan untuk memperoleh laba dari modal yang digunakan untuk menghasilkan data tersebut". Dapat disimpulkan bahwa rasio profitabilitas adalah gambaran ukuran tingkat efektivitas manajemen suatu perusahaan yang biasanya ditunjukkan dari laba yang dihasilkan atas penjualan atau dari pendapatan investasi perusahaan tersebut.

Para kreditur, pemilik perusahaan dan terutama sekali pihak manajemen perusahaan akan berusaha meningkatkan rasio ini, karena disadari betul betapa pentingnya arti keuntungan bagi masa depan perusahaan. Profitabilitas suatu perusahaan dapat diukur dengan menghubungkan antara keuntungan atau laba yang diperoleh dari kegiatan pokok perusahaan dengan kekayaan atau asset yang dimiliki untuk menghasilkan keuntungan perusahaan (operating asset).

Rasio profitabilitas yang dikenal juga dengan nama rasio rentabilitas yang digunakan untuk mengukur kemampuan perusahaan dalam memperoleh keuntungan (profit) yang 


\section{Buletin Ekonomi}

berhubungan dengan total aktiva (total assets), penjualan (sales), dan modal sendiri, dengan demikian analisis profitabilitas merupakan hal yang sangat penting bagi investor jangka panjang. Analisis profitabilitas pemegang saham memungkinkan dapat melihat seberapa besar keuntungan yang akan didapatkan dalam bentuk dividen. Profitabilitas juga menunjukkan kemampuan dari modal yang diinvestasikan dalam keseluruhan aset untuk menghasilkan keuntungan bagi investor.

Penggunaan rasio profitabilitas dapat dilakukan dengan menggunakan perbandingan antara berbagai komponen yang ada di laporan keuangan, terutama laporan keuangan neraca dan laporan laba ruugi. Pengukuran dapat dilakukan untuk beberapa periode operasi. Tujuannya adalah agar terlihat perkembangan perusahaan dalam rentang waktu tertentu, baik penurunan atau kenaikan, sekaligus mencari penyebab perubahan tersebut. Salah satu indikator untuk mengukur profitabilitas adalah dengan menggunakan Return On Assets Ratio. Return On Assets (ROA)

Menurut Agus Sartono (2015:123) Return On Assets adalah kemampuan perusahaan menghasilkan laba dari aktiva yang dipergunakan. Return On Assets menunjukkan kemampuan perusahaan dengan menggunakan seluruh aktiva yang dimiliki untuk menghasilkan laba setelah pajak. Rasio ini penting bagi pihak manajemen untuk mengevalueasi efektivitas dan efisiensi manajemen perusahaan dalam mengelola seluruh aktiva perusahaan.

Menurut Kasmir (2015:201) Return On Assets merupakan ratio yang menunjukan hasil (return) atas jumlah aktiva yang digunakan dalam perusahaan. Maka ROA juga merupakan suatu ukuran tentang efektifitas manajemen dengan mengelola investasinya. Semakin besar ROA, berarti semakin efisien penggunaan aktiva perusahaan atau dengan kata lain dengan jumlah aktiva yang sama bisa dihasilkan laba yang lebih besar, dan sebaliknya. ROA dapat dihitung. Rumus yang digunakan adalah sebagai berikut :

$$
R O A=\frac{\text { Laba bersih setelah pajak }}{\text { total aktiva }} \times 100 \%
$$

Berdasarkan tabel ringkasan penelitian terdahulu (lampiran), maka akan didapatkan kesimpulan bahwa persamaan dalam penelitian ini adalah pada variable independent atau bebas sama-sama membahas tentang laverage, Pertumbuhan Penjualan, serta Ukuran Perusahaan, dan juga profitabilitas sebagai variable dependent. Sedangkan perbedaannya terletak pada jenis perusahaan yang akan diteliti selama 3 (tiga) tahun terakhir guna memberikan informasi terbaru mengenai laverage, pertumbuhan penjualan, ukuran perusahaan terhadap provtabilitas.

\section{Pengaruh Leverage terhadap Profitabilitas}

Leverage merupakan gambaran dari jumlah besar atau kecilnya pemakaian utang oleh suatu perusahaan yang digunakan untuk membiayai aktivitas operasionalnya. Laverage merupakan faktor penting yang mempengaruhi tingkat profitabilitas karena dapat digunakan untuk meningkatkan modal perusahaan guna meningkatkan keuntungan. Menurut Kurniawati (2015) bahwa laverage (Debt to Assets Ratio) berpengaruh positif terhadap profitabilitas, yang berarti bahwa semakin tinggi DAR, maka ROA juga akan meningkat.

\section{Pengaruh Pertumbuhan Penjualan terhadap Profitabilitas}

Semakin tinggi pertumbuhan penjualan perusahaan maka perusahaan akan semakin banyak mengandalkan modal sendiri untuk pembiayaannya. Pertumbuhan penjualan yang tinggi menunjukkan adanya peningkatan pendapatan yang diperoleh dari pernjualan produk operasional perusahaan. Dengan mengetahui seberapa besar pertumbuhan penjualan, perusahaan dapat memprediksi seberapa besar profit yang akan didapatkan. Penjualan harus 


\section{Buletin Ekonomi}

dapat menutupi biaya sehingga dapat meningkatkan profit. Menurut (Putra dan Badjra, 2015) Pertumbuhan penjualan memiliki pengaruh yang strategis bagi perusahaan karena pertumbuhan penjualan ditandai dengan peningkatan market share yang akan berdampak pada peningkatan penjualan dari perusahaan sehingga akan meningkatkan profitabilitas dari perusahaan.

\section{Pengaruh Ukuran Perusahaan terhadap Profitabilitas}

Ukuran perusahaan digunakan untuk mengetahui adanya pengaruh naik dan turunnya profitabilitas. Semakin besar skala perusahaan maka profitabilitas juga akan meningkat, tetapi pada titik atau jumlah tertentu ukuran perusahaan akhirnya akan menurunkan profit (profit) perusahaan. Menurut (Putra dan Badjra, 2015) perusahaan yang lebih besar akan semakin mudah untuk mendapatkan dana dalam jumlah yang besar sehingga akan membantu kegiatan operasional perusahaan dan menyebabkan produktivitas perusahaan meningkat sehingga profitabilitas perusahaan akan meningkat pula. Menurut (Ambarwati, 2015) Ukuran perusahaan bisa dilihat dari total asset perusahaan, karena perusahaan dengan total asset yang besar mencerminkan kemapanan perusahaan.

\section{Model Hipotesis}

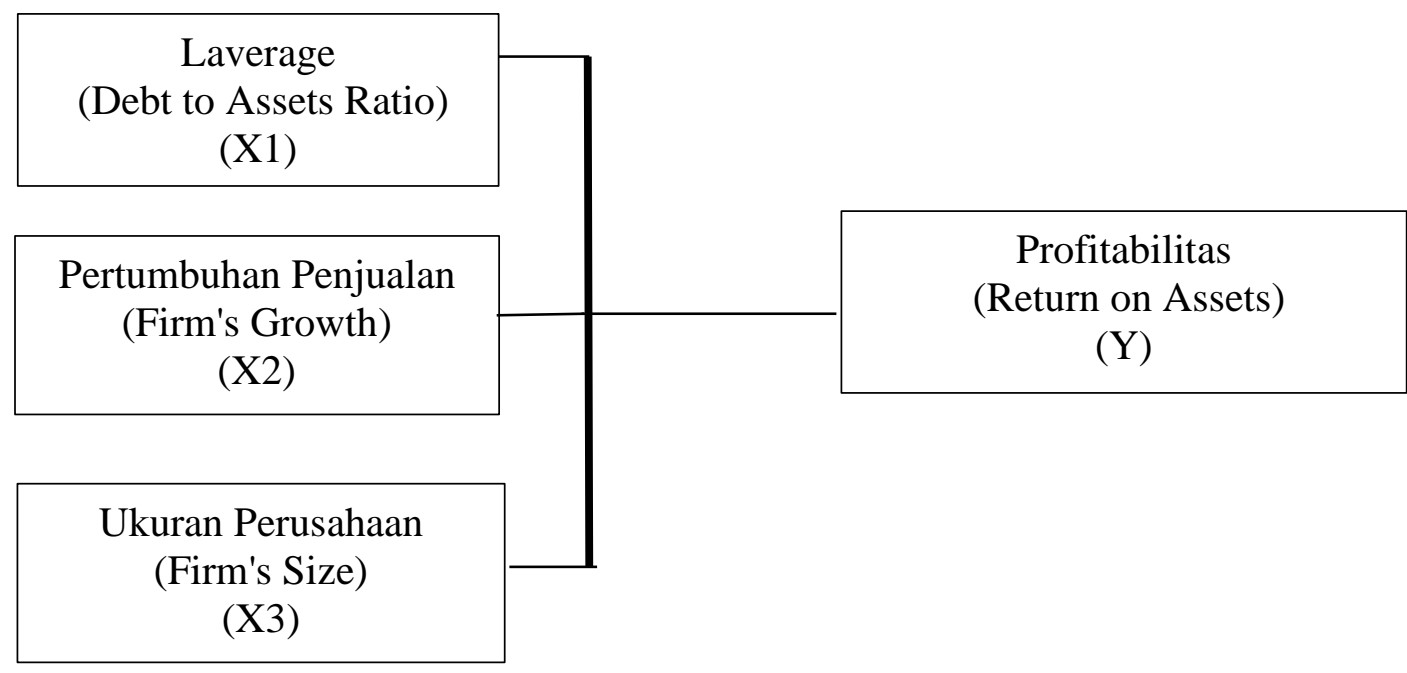

Gambar 1. Model Hipotesis

Dari model hipotesis di atas, dapat dirumuskan hipotesis penelitian sebagai berikut:

$\mathrm{H} 1$ : leverage, pertumbuhan penjualan, dan ukuran perusahaan berpengaruh signifikan terhadap profitabilitas pada perusahaan rokok di Bursa Efek Indonesia. ?

$\mathrm{H} 2$ : leverage berpengaruh positif dan signifikan terhadap profitabilitas pada perusahaan rokok di Bursa Efek Indonesia. ?

H3: Pertumbuhan penjualan berpengaruh positif dan signifikan terhadap profitabilitas pada perusahaan rokok di Bursa Efek Indonesia. ?

H4: Ukuran perusahaan berpengaruh positif dan signifikan terhadap profitabilitas pada perusahaan rokok di Bursa Efek Indonesia.? 


\section{Buletin Ekonomi}

\section{METODE}

Jenis penelitian adalah sebuah desain atau rancangan penelitian. Jenis dan pendekatan yang digunakan dalam penelitian ini adalah kuantitatif. bentuk hubungan antar variabel adalah hubungan kausal/sebab akibat, untuk penelitian kuantitatif adalah analisis data dengan teknik analisis deskriptif kuantitatif, yang pada dasarnya mengubah data hasil penelitian ke dalam bentuk deskripsi angka-angka yang mudah dipahami (Fenti Hikmawati, 2017:92). Penelitian kuantitatif adalah penelitian yang bertujuan untuk mengetahui hubungan antara dua variabel atau lebih yang datanya dinyatakan dalam angka dan dianalisis dengan menggunakan teknik statistik.

Penelitian ini menggunakan penelitian kuantitatif, karena penelitian ini bersifat menganalisa laporan keuangan pada Perusahaan yang terdaftar di Bursa Efek Indonesia dan menafsirkan hasilnya dalam bentuk angka-angka, yang diperoleh dari situs www.icmd.co.id dan www.idx.co.id.

Populasi penelitian ini adalah perusahaan rokok yang terdaftar di Bursa Efek Indonesia, selama tiga tahun dari 2016 sampai dengan tahun 2018. Sampel pada penelitian ini adalah seluruh perusahaan rokok yang terdaftar di Bursa Efek Indonesia, selama tiga tahun dari 2016 sampai dengan tahun 2018.

Teknik pengambilan sampel adalah Purposive sampling. Kriteria yang digunakan untuk memilih sampel pada penelitian ini sebagai berikut: (1) Perusahaan rokok yang akan di analisis telah terdaftar di Bursa Efek Indonesia dengan jangka waktu tiga tahun berturut-turut pada periode 2016-2018, (2) Perusahaan rokok yang terdaftar di Bursa Efek Indonesia menerbitkan laporan keuangan tahunan secara berturut-turut selama periode penelitian dan dapat diakses oleh publik, (3) Perusahaan rokok yang telah menyediakan data yang terkait dengan variabel penelitian, (4) Perusahaan tidak mengalami kerugian selama periode 20162018, (5) Perusahaan yang memiliki nilai Debt to Assets Ratio $>10 \%$ dengan tujuan untuk dapat mengetahui berapa persentase perusahaan menggunakan hutang dibanding dengan modal sendiri, dan (6) Perusahaan yang memiliki nilai aset $>1.000 .000 .000 .000$ (satu triliun).

Dari daftar perusahaan rokok yang terdaftar di Bursa Efek Indonesia yang menjadi populasi penelitian, telah terpilih dan memenuhi kriteria-kriteria diatas untuk dijadikan sebagai sampel penelitian yaitu perusahaan di bidang Industri Rokok.

Tabel 1.

Sampel Penelitian

\begin{tabular}{llc}
\hline No & \multicolumn{1}{c}{ Nama Perusahaan } & Kode Saham \\
\hline 1 & Gudang Garam Tbk & GGRM \\
2 & Bentoel Internasional Investama Tbk & RMBA \\
3 & Wismilak Inti Makmur Tbk & WIIM \\
4 & Hanjaya Mandala Sampoerna Tbk & HMSP \\
\hline
\end{tabular}

\section{Variabel Operasional dan Pengukuran}

Tabel 2.

Variabel Penelitian

\begin{tabular}{lll}
\hline \multicolumn{1}{c}{ Variabel } & \multicolumn{3}{c}{ Defenisi } \\
\hline Profitabilitas & Menurut Sartono dalam Fatmawati (2017:19) \\
(Y) & Profitabilitas adalah kemampuan perusahaan dalam \\
& memperoleh laba dalam hubungannya dengan \\
& penjualan, total aktiva, maupun modal sendiri. \\
\hline Leverage & Laverage digunakan untuk mengukur kemampuan \\
\hline
\end{tabular}




\section{Buletin Ekonomi}

\begin{tabular}{|c|c|}
\hline (X1) & $\begin{array}{l}\text { perusahaan untuk membayar seluruh kewajibannya, } \\
\text { baik jangka pendek maupun jangka panjang apabila } \\
\text { perusahaan dibubarkan (Kasmir,2017:151). }\end{array}$ \\
\hline $\begin{array}{l}\text { Pertu } \\
\text { Penju } \\
\left(\mathrm{X}_{2}\right)\end{array}$ & $\begin{array}{l}\text { Menurut Weston dan Brigham dalam Farhana,dkk } \\
(2016: 5) \text { dengan mengetahui seberapa besar } \\
\text { pertumbuhan penjualan, perusahaan dapat } \\
\text { memprediksi seberapa besar profit yang akan } \\
\text { diperoleh. }\end{array}$ \\
\hline $\begin{array}{l}\text { Ukuran } \\
\text { Perusahaan } \\
\left(\mathrm{X}_{3}\right)\end{array}$ & $\begin{array}{l}\text { Menurut Ernawati (2016) ukuran perusahaan } \\
\text { menggambarkan besar kecilnya suatu perusahaan } \\
\text { yang dapat dinyatakan dengan total aset atau total } \\
\text { penjualan bersih. }\end{array}$ \\
\hline
\end{tabular}

Teknik pengumpulan data yang penulis gunakan untuk memperoleh data yang sesuai dengan tujuan penelitian adalah dokumentasi. Data yang diperoleh dengan metode dokumentasi yang berupa informasi. Untuk itu, peneliti harus mengatur sistematika data tersebut sedemikian rupa dan meminta informasi lebih lanjut kepada pengumpulan data pertama.

Teknik pengumpulan data yang digunakan dalam penelitian ini adalah metode dokumentasi dan kepustakaan sesuai dengan teori di atas. Pengumpulan data yang berkaitan dengan hal-hal atau variabel penelitian diperoleh dengan cara mengumpulkan laporan keuangan terutama yang berkaitan dengan variabel penulis yang telah dipublikasikan pada website www.idx.co.id mulai tahun 2016 sampai 2018.

Uji normalitas adalah bertujuan untuk menguji apakah dalam model regresi, variable pengganggu atau residual mempunyai distribusi normal atau tidak (Sansoethan dan Suryono, 2016) . Uji normalitas digunakan untuk menguji apakah sebuah model regresi, variabel dependen, variabel independen, dan keduanya mempunyai distribusi normal atau tidak.

Uji multikolineritas yaitu hubungan sesama variabel bebas, keadaan dimana variabel - variabel independen dalam pesamaan regresi mempunyai korelasi (hubungan) yang erat satu sama lain. Salah satu tujuan dilakukannya pengujian ini adalah untuk mengetahui apakah sesama variabel independen terjadi korelasi atau hubungan antara satu variabel dengan variabel lain. Uji Multikolinearitas dilakukan dengan model regresi linier klasik apabila memiliki independen lebih dari satu.

Uji Heterokedastisitas bertujuan untuk menguji apakah model regresi terjadi ketidaksamaan varian dari residual satu pengamatan ke pengamatan yang lain. Jika varian dan residual satu pengamatan ke pengamatan yang lain tetap, maka disebut homokedastisitas dan jika berbeda disebut heterokedastisitas (Ghozali, 2016:138). Uji heteroskedastisitas dapat dilakukan dengan dua cara pengujian yaitu dengan melihat grafik dan dengan cara statistik.

Uji autokorelasi digunakan untuk melihat ada tidaknya autkorelasi, autokorelasi adalah korelasi yang terjadi diantara anggota - anggota dari serangkaian pengamatan yang tersusun dalam data time series. Apabila terjadi autokorelasi di dalam suatu model, artinya varian sampel tidak menggambarkan varian populasinya. Autokorelasi yaitu suatu keadaan dimana terjadi korelasi antara residual tahun ini dengan tingkat kesalahan tahun sebelumnya. Model regresi yang baik adalah regresi yang terbebas dari autokorelasi (Ghozali, 2016:106).

Analisis regresi linier berganda adalah hubungan secara linear antara dua atau lebih variabel independen $(\mathrm{X} 1, \mathrm{X} 2, \ldots \ldots \mathrm{Xn})$ dengan variabel $\mathrm{Y}$. Analisis ini untuk mengetahui arah hubungan antar variabel independen dengan variabel dependen apakah masing - masing variabel dependen berhubungan positif atau negatif dan untuk memprediksi nilai variabel dependen apabila nilai variabel independen mengalami kenaikan atau penurunan. Data yang 


\section{Buletin Ekonomi}

digunakan biasanya berskala interval atau rasio. Penelitian ini menggunakan Analisis Regresi linear berganda dengan model Regresi :

$$
\begin{aligned}
& \mathrm{Y}=\mathrm{a}+\mathrm{b} 1 \times 1+\mathrm{b} 2 \times 2+\mathrm{b} 3 \times 3+\mathrm{e} \\
& \text { Dimana : } \\
& \mathrm{Y}=\text { Profitabilitas } \\
& \mathrm{a}=\text { Konstanta } \\
& \mathrm{b} 1=\text { Koefisien Leverage } \\
& \mathrm{x} 1=\text { Leverage } \\
& \text { b2 = Koefisien Pertumbuhan Penjualan } \\
& \mathrm{x} 2=\text { Pertumbuhan Penjualan } \\
& \text { b3 = Koefisien Ukuran Perusahaan } \\
& \mathrm{x} 3=\text { Ukuran Perusahaan } \\
& \mathrm{e}=\text { Standar Error }
\end{aligned}
$$

Menurut Ghozali (2016;96) Uji F disini bertujuan untuk mengetahui apakah variabel bebas (independen) secara bersama-sama berpengaruh terhadap variabel terikat (dependen). Jadi Uji F dalam penelitian ini digunakan untuk menguji ada atau tidaknya pengaruh variabel independen yaitu Leverage, Pertumbuhan Penjualan dan Ukuran Perusahaan secara bersama - sama terhadap variabel dependen yaitu Profitabilitas dari suatu persamaan regresi yang didasarkan pada nilai probabilitas a $=0,05$ dengan kriteria pengujian sebagai berikut :

Jika probabilitas $>0,05$ Ha ditolak, Ho diterima

Jika probabilitas $<0,05$ Ha diterima, Ho ditolak

Uji t digunakan untuk menguji pengaruh variabel independen secara persial terhadap variabel dependen yaitu pengaruh dari variabel independen (Leverage, Pertumbuhan Penjualan dan Ukuran Perusahaan) terhadap variabel dependen yaitu (Profitabilitas) yang didasarkan pada nilai probabilitas a $=0,05$ dengan kriteria pengujian sebagai berikut :

Jika probabilitas > 0,05 Ha ditolak, Ho diterima

Jika probabilitas < 0,05 Ha diterima, Ho ditolak

$t_{\text {hitung }}<\mathrm{t}_{\text {tabel }}$ maka $\mathrm{H}_{\mathrm{a}}$ ditolak dan $\mathrm{H}_{\mathrm{o}}$ diterima

$t_{\text {hitung }}>t_{\text {tabel }}$ maka $\mathrm{H}_{\mathrm{a}}$ diterima dan $\mathrm{H}_{\mathrm{o}}$ ditolak.

\section{ANALISIS DAN PEMBAHASAN}

Gudang Garam adalah produsen rokok kretek terkemuka yang identik dengan Indonesia yang merupakan salah satu sentra utama perdagangan rempah di dunia. Berdasarkan riset pasar Nielsen, pada akhir tahun 2018 Gudang Garam memiliki pangsa pasar rokok dalam negeri sebesar 23,1\% dengan produk-produk yang sudah dikenal luas oleh masyarakat di seluruh Nusantara. Gudang Garam memiliki fasilitas produksi rokok kretek di dua lokasi. Pertama, di Kediri, dengan jumlah penduduk 268 ribu jiwa yang merupakan pusat perdagangan regional sekaligus lokasi kantor pusat Perseroan. Fasilitas produksi kedua berlokasi di Gempol, Jawa Timur yang berjarak 50 kilometer dari Surabaya. Dari kedua fasilitas produksi ini Perseroan mampu memenuhi permintaan produk rokok yang ada. Perseroan memproduksi berbagai jenis rokok kretek, termasuk jenis rendah tar nikotin (LTN) serta produk tradisional sigaret kretek tangan. Saham Perseroan yang tercatat di Bursa Efek Indonesia (BEI) dengan kode GGRM diperdagangkan pada kisaran harga Rp 66.125 hingga Rp 86.400 per lembar saham sepanjang tahun 2018. Jumlah modal disetor dan ditempatkan tidak mengalami perubahan pada tahun 2018 dan Perseroan telah membagikan dividen senilai Rp 2.600 per saham dari laba tahun 2017 sesuai keputusan Rapat Umum Pemegang Saham Tahunan pada bulan Juni 2018. 
PT Hanjaya Mandala Sampoerna Tbk. (“Sampoerna” atau "Perseroan”) telah menjadi bagian penting dari industri tembakau Indonesia selama lebih dari seratus tahun sejak berdiri tahun 1913, dengan produk legendaris Dji Sam Soe atau dikenal dengan "Raja Kretek". Sampoerna adalah pencetus kategori Sigaret Kretek Mesin Kadar Rendah (SKM LT) di Indonesia dengan memperkenalkan produk Sampoerna A pada tahun 1989. Produk Utama dalam Sampoerna $A$ adalah merek terdepan di pasar rokok Indonesia. Perseroan juga memproduksi sejumlah kelompok merek rokok kretek yang telah dikenal luas termasuk Sampoerna Kretek dan Sampoerna U. Perseroan telah memegang posisi pemimpin pasar selama lebih dari 10 tahun di pasar rokok Indonesia, dengan 33,0\% pangsa pasar pada tahun 2018, dan telah menjadi bagian penting industri tembakau Indonesia selama lebih dari seratus tahun dengan produk legendaris Dji Sam Soe yang dikenal sebagai "Raja Kretek". Sampoerna adalah anak perusahaan dari PT Philip Morris Indonesia ("PMID") dan afiliasi dari Philip Morris International Inc. ("PMI"), perusahaan rokok internasional terkemuka dengan merek global Marlboro. Perseroan menjual dan mendistribusikan rokok melalui 114 lokasi kantor cabang zona, kantor penjualan dan pusat distribusi di seluruh pelosok Indonesia. Selama tahun 2018, Sampoerna menerima sejumlah penghargaan sebagai apresiasi atas komitmen Perseroan dalam implementasi tata kelola perusahaan yang baik ("GCG"), program tanggung jawab sosial perusahaan ("CSR"), maupun kinerja bisnis, ekuitas merek, serta kesehatan dan keselamatan kerja. Perseroan juga menerima penghargaan dari Top Employers Institute sebagai peraih peringkat pertama Top Employer Indonesia. Dengan bangga kami juga ingin menyampaikan bahwa PMID sebagai perusahaan induk Sampoerna berhasil memperoleh "Equal-Salary Certification" dari Equal-Salary Foundation. Sebagai bagian dari PMID, Sampoerna tentunya turut berbahagia karena Sampoerna memiliki nilai dan prinsip utama yang sama dengan PMID dan PMID merupakan perusahaan pertama di Indonesia yang menerima sertifikasi ini

PT Bentoel Internasional Investama Tbk. yang beralamat di Jl. Gatot Subroto Kav. 18 Jakarta Selatan 12710 Dalam perjalanannya selama lebih dari delapan dasawarsa, Bentoel Group telah menjadi perusahaan tembakau terbesar keempat di Indonesia. Perusahaan untuk menumbuhkan portofolio yang luar biasa yang meliputi produk-produk tembakau sebagai berikut: ROKOK KRETEK TANGAN Rokok lintingan dengan perpaduan tembakau dan cengkih. Produk-produk utama kami di kategori ini adalah Tali Jagat dan Sejati. ROKOK KRETEK MESIN Rokok yang diproses menggunakan mesin dengan perpaduan tembakau dan cengkih. Produk di bawah kategori ini adalah Dunhill Filter, Dunhill Mild, Lucky Strike Bold dan Lucky Strike Mild. ROKOK PUTIH MESIN Rokok putih yang diproses mengunakan mesin. Produk-produk utama kami di kategori ini adalah Dunhill dan Lucky Strike. Produksi dan distribusi sederet produk Perusahaan tersebut dilakukan di bawah aktivitas bisnis industri tembakau serta distribusi rokok. Kegiatan usaha ini sejalan dengan Anggaran Dasar Perusahaan.

Perjalanan historis Wismilak di industri rokok dimulai pada tahun 1962 dengan didirikannya PT Gelora Djaja yang bergerak sebagai produsen rokok kretek premium merek Galan, Wismilak, dan Diplomat. Sejak awal pendirian, Wismilak telah berkomitmen untuk menghadirkan pengalaman berbeda kepada konsumen melalui diferensiasi produk rokok premium dengan racikan yang khas dan bumbu-bumbu berkualitas. Selanjutnya guna menjaga keberlangsungan usaha, Perseroan melakukan ekspansi bisnis dengan mendirikan PT Gawih Jaya pada 1983 yang berperan sebagai perusahaan distributor produk-produk kretek milik PT Gelora Djaja ke seluruh wilayah Nusantara. PT Wismilak Inti Makmur ditetapkan memiliki kegiatan usaha berupa pemasaran dan penjualan produk rokok dan kelengkapannya serta penyertaan pada produsen rokok kretek. Dalam perjalanannya, Wismilak terus beradaptasi dengan teknologi yang semakin canggih hingga akhirnya 


\section{Buletin Ekonomi}

menghadirkan varian Sigaret Kretek Mesin (SKM) untuk kretek filter dan produk cerutu. Meski begitu, Wismilak tetap menjaga keotentikan produknya yang telah dikenal dekat oleh Konsumen dengan tetap memproduksi Sigaret Kretek Tangan (SKT) dengan proses pengerjaan dengan peralatan non-mesin. Sejalan dengan pengembangan internal yang terus dilakukan, Wismilak bertekad untuk meningkatkan kapasitas dan kapabilitas usaha dengan melakukan penawaran saham umum perdana di Bursa Efek Indonesia pada 18 Desember 2012 dengan kode saham WIIM. Melantainya Perseroan di bursa telah memberikan penguatan pada struktur modal Perseroan sehingga Perseroan mampu melakukan pengembangan usaha seraya tak lupa menjalankan prinsip-prinsip pengelolaan perusahaan yang baik berdasarkan prinsip Good Corporate Governance ("GCG"). Transformasi Perseroan menjadi perusahaan publik membuat Perseroan semakin teguh dan bertekad kuat menjunjung prinsip transparansi dan akuntabilitas dalam kegiatan tata kelola perusahaan.

\section{Analisis Deskriptif}

Tabel 3.

Hasil Uji Analisis Deskriptif

\begin{tabular}{lrrrrr}
\hline & \multicolumn{2}{c}{$\begin{array}{c}\text { Laverage } \\
(\mathrm{X} 1)\end{array}$} & $\begin{array}{r}\text { Pertumbuhan } \\
\text { Penjualan }(\mathrm{X} 2)\end{array}$ & $\begin{array}{c}\text { Ukuran } \\
\text { Perusahaan }(\mathrm{X} 3)\end{array}$ & $\begin{array}{r}\text { Profitabilitas } \\
(\mathrm{Y})\end{array}$ \\
\hline $\mathrm{N} \quad$ Valid & 12 & 12 & 12 & 12 \\
& Missing & 0 & 0 & 0 & 0 \\
Mean & 29,2123 & 4,42 & 13,25 & 9,50 \\
Std. Error & & &, 250 & 4,133 \\
Mean & 2,42814 & 2,435 & 13,50 & 9,50 \\
Median & 28,3479 & 7,50 & 14 & $11^{\mathrm{a}}$ \\
Mode & $19,60^{\mathrm{a}}$ & 8 &, 866 & 14,318 \\
Std. Deviation & 8,41133 & 8,436 &, 750 & 205,000 \\
Variance & 70,750 & 71,174 & 2 & 46 \\
Range & 24,17 & 27 & 12 & -16 \\
Minimum & 19,60 & -12 & 14 & 30 \\
Maximum & 43,78 & 15 & &
\end{tabular}

Berdasarkan tabel 4, nilai rata-rata variabel Laverage adalah sebesar 29,2123 dengan standar deviasi sebesar 8,41133 serta nilai tertinggi sebesar 43,78 yaitu pada perusahaan PT Bentoel Internasional Investama Tbk pada tahun 2018. Nilai rata-rata Laverage lebih besar dari standar deviasinya maka secara statistik data telah bernilai positif dan baik untuk pengujian selanjutnya.

Nilai rata- rata variabel pertumbuhan penjualan adalah sebesar 4,42 dengan standar deviasi sebesar 8,436 serta nilai tertinggi sebesar 15 yaitu perusahaan PT Gudang Garam Tbk pada tahun 2018 dan nilai terendah sebesar (-12) yaitu perusahaan PT Wismilak Inti Makmur pada tahun 2017. Nilai rata-rata pertumbuhan penjualan lebih kecil dari standar deviasinya maka secara statistik data bernilai negatif, akan tetapi tidak mempengaruhi kualitas data yang akan diteliti.

Nilai rata- rata variabel ukuran perusahaan adalah sebesar 13,25 dengan standar deviasi sebesar 0,866 serta nilai tertinggi sebesar 14 yaitu perusahaan PT Gudang Garam Tbk dan PT Hanjaya Mandala Sampoerna Tbk. nilai terendah sebesar 12 yaitu perusahaan PT Wismilak Inti Makmur Tbk. Nilai rata-rata ukuran perusahaan lebih besar dari standar deviasinya maka secara statistik data telah bernilai positif dan baik untuk pengujian selanjutnya. 


\section{Buletin Ekonomi}

Nilai rata- rata variabel profitabilitas adalah sebesar 9,50 dengan standar deviasi sebesar 14,318 serta nilai tertinggi sebesar 30 yaitu perusahaan PT Hanjaya Mandala Sampoerna Tbk pada tahun 2016 dan nilai terendah sebesar -16 yaitu perusahaan PT Bentoel Internasional Investama Tbk pada tahun 2016. Nilai rata-rata profitabilitas lebih kecil dari standar deviasinya maka secara statistik data bernilai negatif, akan tetapi tidak mempengaruhi kualitas data yang akan diteliti.

Uji normalitas pada penelitian ini menggunakan dua cara yaitu secara grafik Normal Probability -Plot atau Normal P-P Plot, serta uji statistic non-parametrik KolmogorovSmirnov (K-S), yang apabila Asymp. Sig (2-tailed) $>\alpha(0,05)$ maka dikatakan data berdistribusi normal, sedangkan jika hasil $<0,05$ maka data tidak berdistribusi normal. Hasil uji normalitas untuk penelitian ini dapat dilihat dari hasil analisa data berikut :

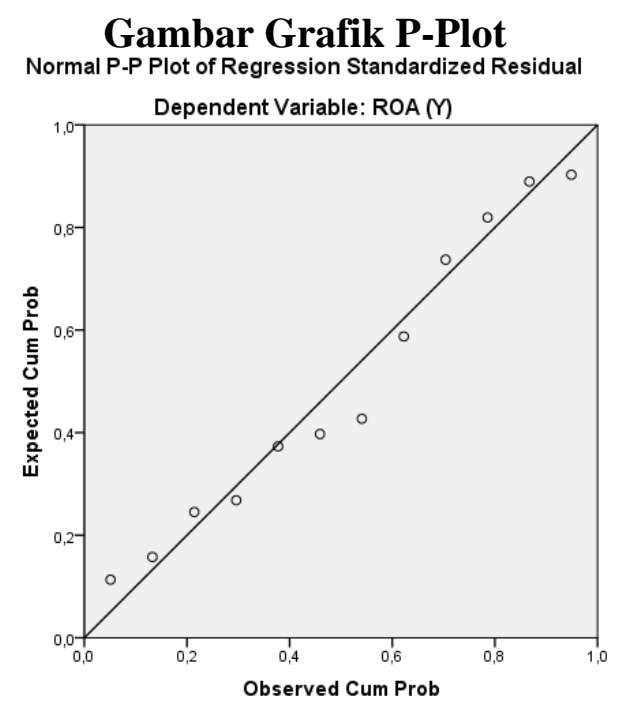

Gambar 2. Grafik P-Plot

Pada gambar grafik P-Plot menunjukkan bahwa data ploting mengikuti daris diagonal yang mengatakan bahwa model regresi berdistribusi normal.

Tabel 4.

One-Sample Kolmogorov-Smirnov Test

\begin{tabular}{|c|c|c|}
\hline & \multicolumn{2}{|c|}{$\begin{array}{l}\text { Unstandardized } \\
\text { Residual }\end{array}$} \\
\hline$\overline{\mathrm{N}}$ & & 12 \\
\hline Normal Parameters ${ }^{\mathrm{a}, \mathrm{b}}$ & Mean &, 0000000 \\
\hline & $\begin{array}{l}\text { Std. } \\
\text { Deviation }\end{array}$ & 4,96404567 \\
\hline $\begin{array}{ll}\text { Most } & \text { Extreme } \\
\text { Differences } & \end{array}$ & Absolute & , 169 \\
\hline & $\begin{array}{l}\text { Positive } \\
\text { Negative }\end{array}$ & $\begin{array}{r}, 169 \\
-, 108\end{array}$ \\
\hline $\begin{array}{l}\text { Test Statistic } \\
\text { Asymp. Sig. (2-tailed) }\end{array}$ & & $\begin{array}{r}, 169 \\
, 200^{\mathrm{c}, \mathrm{d}}\end{array}$ \\
\hline
\end{tabular}

Tabel di atas menunjukkan bahwa nilai signifikansi atau nilai Asymp. Sig sebesar 0,200 atau > 0,05. Hal ini menunjukkan bahwa model regresi berdistribusi normal dan 


\section{Buletin Ekonomi}

memenuhi asumsi normalitas, sesuai yang telah ditunjukkan oleh kedua cara penguian pada tabel diatas, sehingga dapat dihunakan dalam analisis parametrik.

Untuk menemukan ada atau tidaknya gelaja multikolinearitas dalam model regresi dapat diketahui dengan melihat nilai Tolerance dan Variance Inflation Factor (VIF), dapat dikatakan tidak terjadi multikolinearitas apabila nilai Tolerance > 0,100 dan nilai VIF < 10,00 .

Tabel 5.

Hasil Uji Multikolinearitas

\begin{tabular}{|c|c|c|c|c|c|c|c|c|}
\hline & \multirow[b]{2}{*}{ Model } & \multicolumn{2}{|c|}{$\begin{array}{l}\text { Unstandardized } \\
\text { Coefficients } \\
\text { Std. }\end{array}$} & \multicolumn{2}{|l|}{$\begin{array}{l}\text { Standardized } \\
\text { Coefficients }\end{array}$} & \multicolumn{3}{|c|}{$\begin{array}{l}\text { Collinearity } \\
\text { Statistics }\end{array}$} \\
\hline & & B & Error & Beta & $\mathrm{t}$ & Sig. & Tolerance & VIF \\
\hline \multirow[t]{4}{*}{1} & (Constant) & $-193,665$ & 35,617 & & $-5,437$ & ,001 & & \\
\hline & DAR (X1) &,- 704 & ,245 &,- 414 & $-2,871$ & 021 & ,723 & 1,383 \\
\hline & $\begin{array}{l}\text { Pertumbuhan } \\
\text { Penjualan (X2) }\end{array}$ & $-1,739$ & ,532 &,- 609 & $-3,271$ & ,011 & ,433 & 2,311 \\
\hline & Size (X3) & 17,740 & 2,728 & 1,072 & 6,503 & ,000 &, 552 & 1,812 \\
\hline
\end{tabular}

Tabel di atas menunjukkan bahwa nilai tolerance variabel Laverage (X1), Pertumbuhan Penjualan (X2) dan Ukuran Perusahaan (X3) secara berturut-turut adalah sebesar 0,723 ; 0,433 ; dan 0,552 yang menunjukkan bahwa nilai tolerance dari variabel $\mathrm{X} 1$, $\mathrm{X} 2$ dan X3 > 0,100, serta nilai VIF secara berturut-turut adalah sebesar 1,$383 ; 2,311$; dan 1,812 yang menunjukkan bahwa nilai VIF dari variabel X1, X2 dan X3 < 10,00. Sehingga dapat disimpulkan bahwa model regresi terbebas dari gejala multikolinearitas.

\section{Uji Heteroskedastisitas}

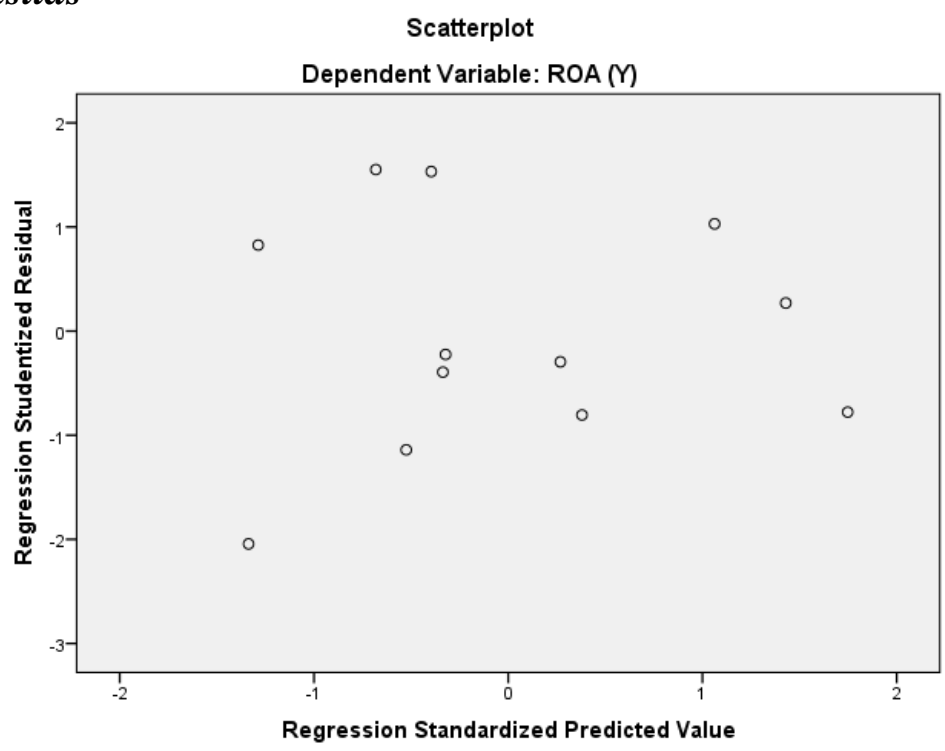

Gambar 3. Scatter Plot 


\section{Buletin Ekonomi}

Berdasarkan gambar di atas terbukti bahwa tidak ada pola tertentu pada grafik gambar scatterplot, dan yang terjadi pada grafik tersebut yaitu titik- titik yang menyebar di atas dan di bawah angka 0 pada sumbu Y tanpa adanya pola tertentu. Maka berdasarkan uji scatterplot disimpulkan bahwa tidak terjadi gelaja heteroskedastisitas.

Tabel 6.

Hasil Uji Heteroskedastisitas

\begin{tabular}{|c|c|c|c|c|c|c|}
\hline \multirow{2}{*}{\multicolumn{2}{|c|}{ Model }} & \multicolumn{2}{|c|}{$\begin{array}{l}\text { Unstandardized } \\
\text { Coefficients }\end{array}$} & \multirow{2}{*}{$\begin{array}{c}\text { Standardized } \\
\text { Coefficients } \\
\text { Beta }\end{array}$} & \multirow[b]{2}{*}{$\mathrm{t}$} & \multirow[b]{2}{*}{ Sig. } \\
\hline & & B & Std. Error & & & \\
\hline \multirow[t]{4}{*}{1} & (Constant) & 17,659 & 14,627 & & 1,207 & 262 \\
\hline & DAR (X1) & ,028 &, 101 & , 100 & 282 & ,785 \\
\hline & $\begin{array}{l}\text { Pertumbuhan Penjualan } \\
\text { (X2) }\end{array}$ & , 300 & 218 & ,629 & 1,376 & ,206 \\
\hline & Size (X3) & $-1,229$ & 1,120 &,- 444 & $-1,097$ &, 305 \\
\hline
\end{tabular}

Berdasarkan hasil uji heteroskedastisitas ditemukan bahwa nilai signifikansi variabel Laverage (X1), Pertumbuhan Penjualan (X2) dan Ukuran Perusahaan (X3) secara berturutturut adalah sebesar 0,$785 ; 0,206$; dan 0,305 yang menunjukkan bahwa nilai signifikansi dari ketiga variabel $\mathrm{X} 1, \mathrm{X} 2$, dan $\mathrm{X} 3>0,05$. Sehingga dapat dikatakan tidak terjadi gelaja heteroskedastisitas atau uji heteroskedastisitas telah terpenuhi.

Dengan menggunakan uji Durbin Watson dapat diambil keputusan ada atau tidaknya gejala autokorelasi dengan melihat nilai Durbin Watson sebagai berikut :

1. DU < DW < 4-DU, artinya tidak terjadi autokorelasi.

2. DW $<$ DL atau DW $>4-$ DL, artinya terjadi autokorelasi.

3. DL $<$ DW $<$ DU atau $4-$ DU $<$ DW $<4-$ DL, artinya tidak ada kepastian atau kesimpulan yang pasti.

Tabel 7.

Hasil Uji Autokorelasi

\begin{tabular}{cccccc}
\hline Model & $\mathrm{R}$ & R Square & $\begin{array}{c}\text { Adjusted R } \\
\text { Square }\end{array}$ & $\begin{array}{c}\text { Std. Error of the } \\
\text { Estimate }\end{array}$ & Durbin-Watson \\
\hline 1 &, $938^{\mathrm{a}}$ &, 880 &, 835 & 5,8209 & 2,095 \\
\hline
\end{tabular}

Berdasarkan tabel di atas diketahui bahwa nilai Durbin-Watson menunjukkan sebesar 2,095 .

Diketahui : $\mathrm{k}=3, \mathrm{~N}=12$ dengan $\alpha=5 \%$

Nilai du pada distribusi nilai tabel Durbin Watson yaitu 1,8640

$4-\mathrm{du}=4-1,8640=2,136$

Maka : du $(1,8640)<$ Durbin Watson $(2,095)<4-$ du $(2,136)$

Berdasarkan Uji Durbin Watson dahwa nilai Durbin Watson terletak antara du sampai dengan (4-du), sehingga tidak terdapat autokorelasi pada bentuk penelitian ini, sehingga data dapat digunakan pada uji statistik selanjutnya.

Uji Regresi Berganda digunakan untuk melihat perubahan dari nilai variabel dependen jika dihadapkan kepada variabel independen. Rumus regresi linear berganda adalah $: Y=a+b_{1} X_{1}+b_{2} X_{2}+b_{3} X_{3}+e$ 


\section{Buletin Ekonomi}

Tabel 8.

Coefficients $^{\text {a }}$

\begin{tabular}{|c|c|c|c|c|c|c|}
\hline & \multirow[b]{2}{*}{ Model } & \multicolumn{2}{|c|}{$\begin{array}{l}\text { Unstandardized } \\
\text { Coefficients }\end{array}$} & \multirow{2}{*}{$\begin{array}{c}\text { Standardized } \\
\text { Coefficients } \\
\text { Beta } \\
\end{array}$} & \multirow[b]{2}{*}{$\mathrm{t}$} & \multirow[b]{2}{*}{ Sig. } \\
\hline & & B & Std. Error & & & \\
\hline \multirow[t]{4}{*}{1} & (Constant) & $-193,665$ & 35,617 & & $-5,437$ &, 001 \\
\hline & DAR (X1) &,- 704 & ,245 &,- 414 & $-2,871$ & ,021 \\
\hline & $\begin{array}{l}\text { Pertumbuhan Penjualan } \\
\text { (X2) }\end{array}$ & $-1,739$ & ,532 &,- 609 & $-3,271$ & ,011 \\
\hline & Size (X3) & 17,740 & 2,728 & 1,072 & 6,503 &, 000 \\
\hline
\end{tabular}

Berdasarkan analisis data pada diatas maka dapat dibuat persamaan regresi linear berganda sebagai berikut:

$$
Y=-193,665-0,704 X_{1}-1,739 X_{2}+17,740 X_{3}
$$

Persamaan regresi linear berganda tersebut menunjukkan arah masing-masing variabel bebas terhadap variabel terikatnya, dimana koefisien regresi variabel bebas yang bertanda positif berarti mempunyai pengaruh yang searah terhadap profitabilitas dan yang bertanda negatif berarti mempunyai pengaruh yang berlawanan arah terhadap profitabilitas.

Tabel 9.

Model Summary ${ }^{\mathrm{b}}$

\begin{tabular}{cccccc}
\hline Model & $\mathrm{R}$ & R Square & $\begin{array}{c}\text { Adjusted R } \\
\text { Square }\end{array}$ & $\begin{array}{c}\text { Std. Error of the } \\
\text { Estimate }\end{array}$ & Durbin-Watson \\
\hline 1 &, $938^{\mathrm{a}}$ &, 880 &, 835 & 5,8209 & 2,095 \\
\hline
\end{tabular}

Berdasarkan hasil analisis pada tabel diatas nilai Adjusted R Square menunjukkan sebesar 0,835 . Ini berarti bahwa $83,5 \%$ variasi profitabilitas dipengaruhi oleh laverage, pertumbuhan penjualan, dan ukuran perusahaan sedangkan sisanya $16,5 \%$ dipengaruhi oleh faktor-faktor lain yang tidak dimasukkan dalam model penelitian.

Tabel 10.

ANOVA ${ }^{a}$

\begin{tabular}{|c|c|c|c|c|c|c|}
\hline & Model & $\begin{array}{c}\text { Sum of } \\
\text { Squares }\end{array}$ & $\mathrm{df}$ & Mean Square & $\mathrm{F}$ & Sig. \\
\hline \multirow[t]{3}{*}{1} & Regression & 1987,270 & 3 & 662,423 & 19,551 &, $000^{\mathrm{b}}$ \\
\hline & Residual & 271,059 & 8 & 33,882 & & \\
\hline & Total & 2258,329 & 11 & & & \\
\hline
\end{tabular}

Berdasarkan hasil Uji $\mathrm{F}$ pada tabel Anova dapat dilihat bahwa nilai signifikan menunjukkan sebesar 0,000 atau $<0,05$. Sehingga dapat disimpulkan bahwa variabel independen berpengaruh secara simultan (bersama-sama) terhadap variabel dependen. Dengan kata lain bahwa laverage, pertumbuhan penjualan dan ukuran perusahaan berpengaruh terhadap profitabilitas.

Menurut (V.Wiratna Sujarweni ,2014;154) jika nilai $F_{\text {hitung }}>F_{\text {tabel }}$ maka artinya variabel independen secara simultan berpengaruh terhadap variabel dependen.

Diketahui; $\mathrm{F}_{\text {tabel }}=(\mathrm{k} ; \mathrm{n}-\mathrm{k})=(3 ; 12-3)=(3 ; 9)=3,86$

Nilai pada $F_{\text {tabel }}$ sebesar 3,86

Maka diperoleh perhitungan $F_{\text {hitung }}(19,551)>F_{\text {tabel }}(3,86)$ 


\section{Buletin Ekonomi}

Berdasarkan hasil uji $\mathrm{F}$ baik uji tabel maupun uji $\mathrm{F}$ hitung menunjukkan adanya pengaruh variabel independen secara simultan terhadap variabel dependen.

Pengujian ini dilakukan dengan melihat nilai signifikansi, jika nilai signifikansi $<0,05$ maka artinya variabel independen secara parsiap berpengaruh terhadap variabel dependen.

\begin{tabular}{|c|c|c|c|c|c|c|}
\hline \multicolumn{7}{|c|}{$\begin{array}{l}\text { Tabel } 11 . \\
\text { Hasil Uji t }\end{array}$} \\
\hline & \multirow[b]{2}{*}{ Model } & \multicolumn{2}{|c|}{$\begin{array}{c}\text { Unstandardized } \\
\text { Coefficients }\end{array}$} & \multirow{2}{*}{$\begin{array}{c}\text { Standardized } \\
\text { Coefficients } \\
\text { Beta }\end{array}$} & \multirow[b]{2}{*}{$\mathrm{t}$} & \multirow[b]{2}{*}{ Sig. } \\
\hline & & B & Std. Error & & & \\
\hline \multirow[t]{4}{*}{1} & (Constant) & $-193,665$ & 35,617 & & $-5,437$ & ,001 \\
\hline & DAR (X1) &,- 704 &, 245 &,- 414 & $-2,871$ & 021 \\
\hline & $\begin{array}{l}\text { Pertumbuhan } \\
\text { Penjualan (X2) }\end{array}$ & $-1,739$ &, 532 &,- 609 & $-3,271$ & ,011 \\
\hline & Size (X3) & 17,740 & 2,728 & 1,072 & 6,503 & ,000 \\
\hline
\end{tabular}

Berdasarkan hasil Uji t menunjukkan bahwa nilai signifikan pada variabel X1, X2 dan X3 secara berturut-turut sebesar 0,$021 ; 0,011$ dan 0,000 yang secara beturut-turut menunjukkan $<0,05$. Sehingga dapat disimpulkan bahwa variabel independen berpengaruh secara parsial terhadap variabel dependen. Dengan kata lain bahwa laverage berpengaruh terhadap profitabilitas, pertumbuhan penjualan berpengaruh terhadap profitabilitas dan ukuran perusahaan berpengaruh terhadap profitabilitas.

Menurut (V.Wiratna Sujarweni ,2014;155) jika nilai $t_{\text {hitung }}>t_{\text {tabel }}$ maka artinya variabel independen secara parsial berpengaruh terhadap variabel dependen.

Diketahui; $\mathrm{t}_{\text {tabel }}=(\alpha / 2 ; \mathrm{n}-\mathrm{k}-1)=(0,05 / 2 ; 12-3-1)=(0,025 ; 8)=2,306$

Nilai pada tabel sebesar 2,306

Maka diperoleh perhitungan nilai pada variabel:

(X1) bahwa $t_{\text {hitung }}(2,871)>t_{\text {tabel }}(2,306)$

(X2) bahwa $t_{\text {hitung }}(3,271)>t_{\text {tabel }}(2,306)$

(X3) bahwa $t_{\text {hitung }}(6,503)>t_{\text {tabel }}(2,306)$

Berdasarkan hasil uji t baik uji tabel maupun uji t hitung menunjukkan adanya pengaruh variabel independen secara parsial terhadap variabel dependen. Dengan kata lain bahwa laverage (X1) berpengaruh terhadap profitabilitas $(\mathrm{Y})$, pertumbuhan penjualan (X2) berpengaruh terhadap profitabilitas (Y) dan ukuran perusahaan (X3) berpengaruh terhadap profitabilitas (Y).

\section{Pengaruh Leverage (DAR) terhadap Profitabilitas (ROA)}

Berdasarkan signifikansi, jika signifikansi $<0,05$ maka terdapat pengaruh yang signifikan, dan jika signifikansi > 0,05 maka tidak terdapat pengaruh yang signifikan. Berdasarkan signifikansi uji t telah didapatkan hasil bahwa uji t lebih dari 0,05 dan

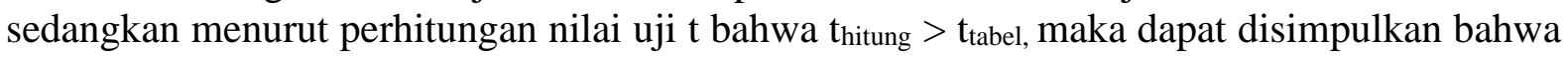
laverage (DAR) berpengaruh secara parsial terhadap profitabiitas (ROA). Berdasarkan analisa regresi linear berganda dimana jika leverage meningkat maka profitabilitas akan menurun. Hal ini sesuai dengan nilai bersifat negatif, sehingga leverage berpengaruh negatif dan signifikan terhadap profitabilitas dimana setiap peningkatan leverage maka profibalitas akan mengalami penurunan.

Leverage dalam penelitian ini menggambarkan penggunaan utang dalam membiayai investasi perusahaan. Investasi yang dimaksud adalah penggunaan aktiva perusahaan. Nilai leverage menjelaskan proporsi tingkat dana perusahaan dalam membayar beban tetap. Apabila rasio leverage atau utang meningkat maka penggunaan aktiva perusahaan menjadi 


\section{Buletin Ekonomi}

tidak efektif karena digunakan untuk menutupi beban tetap (kewajiban) perusahaan atas pelunasan hutang-hutangnya, sehingga akan menurunkan laba perusahaan (profitabilitas). Penggunaan hutang dalam kegiatan pendanaan perusahaan tidak hanya memberikan dampak yang baik tetapi juga akan memperoleh resiko yang cukup besar, karena jika proporsi laverage tidak diperhatikan maka akan berdampak menurunkan profitabilitas paerusahaan karena penggunaan hutang menimbulkan beban bunga yang bersifat tetap.

Hasil dari analisis ini menunjukkan bahwa laverage berpengaruh negatif dan signifikan terhadap profitabilitas, jika leverage meningkat maka profitabilitas perusahaan akan menurun. Pengaruh yang signifikan menunjukkan bahwa leverage merupakan faktor utama yang mempengaruhi profitabilitas perusahaan. Dan juga tingkat laverage yang tinggi akan memiliki resiko yang tinggi karena adanya biaya hutang yang lebih besar. Hutang yang besar akan menyebabkan profitabilitas perusahaan menurun atau menjadi rendah karena perhatian perusahaan dialihkan dari peningkatan produktivitas menjadi kebutuhan untuk menghasilkan arus kas untuk melunasi hutang perusahaan. Perusahaan yang menghasilkan laba yang tinggi, akan menggunakan hutang yang relatif sedikit karena perusahaan akan cenderung menggunakan dana internalnya.

\section{Pengaruh pertumbuhan penjualan terhadap Profitabilitas (ROA)}

Berdasarkan signifikansi, jika signifikansi $<0,05$ maka terdapat pengaruh yang signifikan, dan jika signifikansi > 0,05 maka tidak terdapat pengaruh yang signifikan. Berdasarkan signifikansi uji t telah didapatkan hasil bahwa uji t lebih dari 0,05 dan juga berdasarkan perhitungan uji $t$ menurut nilai bahwa thitung $>t_{t a b e l}$, maka dapat disimpulkan bahwa pertumbuhan penjualan berpengaruh secara parsial terhadap profitabiitas (ROA).Berdasarkan analisis regresi linear berganda dimana jika pertumbuhan penjualan meningkat maka profitabilitas akan menurun. Hasil ini sesuai dengan nilai bersifat negatif, sehingga pertumbuhan penjualan berpengaruh negatif dan signifikan terhadap profitabilitas dimana setiap peningkatan pertumbuhan penjualan maka profibalitas akan mengalami penurunan.

Hasil dari analisis ini menunjukkan bahwa pertumbuhan penjualan berpengaruh negatif dan signifikan terhadap profitabilitas. Jika pertumbuhan penjualan meningkat maka profitabilitas perusahaan akan menurun. Pengaruh yang signifikan menunjukkan bahwa pertumbuhan penjualan merupakan faktor utama yang mempengaruhi profitabilitas perusahaan. Dalam hal ini penjualan harus dapat menutupi biaya, sehingga dapat meningkatkan keuntungan. Apabila pertumbuhan penjualan disertai dengan peningkatan biaya dan penambahan aktiva yang lebih besar maka mengakibatkan peningkatan profitabilitas yang diharapkan tidak dapat tercapai karena pertumbuhan penjualan tidak dapat menutupi biaya yang dikeluarkan oleh perusahaan. Jadi dengan kata lain bahwa perusahaan pengelolaan keuangan perusahaan menjadi teralihkan karena dengan penambahan aset dan juga adanya biaya yang besar maka perusahaan harus membayar beban tetap dari aset perusahaan tersebut, sedangkan biaya untuk meningkatkan pertumbuhan penjualannya harus diperhatikan juga.

\section{Pengaruh ukuran perusahaan terhadap profitabilitas (ROA)}

Berdasarkan signifikansi, jika signifikansi $<0,05$ maka terdapat pengaruh yang signifikan, dan jika signifikansi > 0,05 maka tidak terdapat pengaruh yang signifikan. Berdasarkan signifikansi uji t telah didapatkan hasil bahwa uji t lebih dari 0,05 dan juga berdasarkan perhitungan uji $t$ menurut nilai bahwa thitung $>t_{\text {tabel, }}$ maka dapat disimpulkan bahwa ukuran perusahaan berpengaruh secara parsial terhadap profitabiitas (ROA). Berdasarkan analisisregresi linear berganda dimana jika ukuran perusahaan meningkat maka profitabilitas akan meningkat. Hasil ini sesuai dengan nilai bersifat positif, sehingga ukuran perusahaan berpengaruh positif dan signifikan terhadap profitabilitas. 


\section{Buletin Ekonomi}

Hasil dari analisis menunjukkan bahwa ukuran perusahaan berpengaruh positif dan signifikan terhadap profitabilitas. Jika ukuran perusahaan meningkat maka profitabilitas (ROA) perusahaan akan meningkat. Pengaruh yang signifikan menunjukkan bahwa ukuran perusahaan merupakan faktor utama yang mempengaruhi profitabilitas perusahaan. Semakin maksimal aktiva perusahaan, maka laba yang akan didapat juga menjadi maksimal, karena aktiva perusahaan digunakan untuk kegiatan operasional perusahaan. Dalam hal ini, ukuran perusahaan merupakan gambaran yang di berikan oleh perusahaan untuk pihak eksternal, sehingga pihak eksternal perusahaan dapat mengetahui tingkat kemapanan dari perusahaan. Semakin besar ukuran perusahaan merupakan suatu sinyal positif yang akan mendapatkan kepercayaan dari investor yang berdampak pada peningkatan harga pasar saham dari perusahaan. Selain itu jika jumlah asset yang dimiliki oleh perusahaan tergolong besar maka akan menunjukkan kualitas serta kinerja yang baik dari perusahaan tersebut. Semakin besar aktiva yang dimiliki perusahaan menunjukkan semakin tinggi profit yang dihasilkan.

\section{Pengaruh laverage, pertumbuhan penjualan dan ukuran perusahaan terhadap profitabilitas}

Berdasarkan signifikansi, jika signifikansi $<0,05$ maka terdapat pengaruh yang signifikan, dan jika signifikansi > 0,05 maka tidak terdapat pengaruh yang signifikan. Berdasarkan signifikansi uji $\mathrm{f}$ telah didapatkan hasil bahwa uji t lebih dari 0,05 yaitu sebesar 19,551 dan juga berdasarkan perhitungan uji $\mathrm{F}$ menurut nilai bahwa $F_{\text {hitung }}>F_{\text {tabel, }}$ maka dapat disimpulkan bahwa ukuran perusahaan berpengaruh secara simultan terhadap profitabiitas (ROA). Dan berdasarkan nilai adjusted $\mathrm{R}$ Square bahwa nilai Adjusted $\mathrm{R}$ Square menunjukkan sebesar 0,835. Ini berarti bahwa 83,5\% variasi profitabilitas dipengaruhi oleh laverage, pertumbuhan penjualan, dan ukuran perusahaan sedangkan sisanya 16,5\% dipengaruhi oleh faktor-faktor lain yang tidak dimasukkan dalam model penelitian. Jadi laverage, pertumbuhan penjualan dan ukuran perusahaan merukapan faktor terbesar terkait dengan profitabilitas.

\section{KESIMPULAN DAN SARAN}

\section{Kesimpulan}

Berdasarkan hasil penelitian dan pembahasan yang telah diuraikan bahwa leverage berpengaruh negatif dan signifikan terhadap profitabilitas pada perusahaan rokok yang terdaftar di BEI selama periode 2016-2018, pertumbuhan penjualan berpengaruh negatif dan signifikan terhadap profitabilitas pada perusahaan rokok yang terdaftar di BEI selama periode 2016-2018. Akan tetapi ukuran perusahaan memiliki pengaruh positif dan signifikan terhadap profitabilitas pada perusahaan rokok yang terdaftar di BEI selama periode 20162018. Dan setiap variabel independen memiliki pengaruh yang positif dan signifikan terhadap variabel dependen secara simultan yaitu leverage, pertumbuhan penjualan dan ukuran perusahaan yang memiliki pengaruh signifikan terhadap profitabilitas pada perusahaan rokok yang terdaftar di BEI selama periode 2016-2018. Jadi dapat diambil kesimpulan bahwa setiap variabel independen memiliki pengaruh yang signifikan terhadap variabel dependen baik secara parsial maupun secara simultan.

Berdasarkan kesimpulan yang telah dikemukakan, maka manajer perusahaan dalam rencana meningkatkan profitabilitas, maka perlu memperhatikan ukuran perusahaan, pertumbuhan penjualan dan leverage (DER) karena telah terbukti mempunyai pengaruh yang signifikan terhadap profitabilitas. Akan tetapi perlu deperhatikan leverage dan pertumbuhan penjualan karena meski mampu dianggap sebagai faktor kenaikan profitabilitas , pada kondisi tertentu kenaikan 2 variabel tersebut tidak akan mempengaruhi kenaikan profitabilitas.

Keterbatasan Penelitian 


\section{Buletin Ekonomi}

Penelitian ini mempunyai beberapa keterbatasan, antara lain: (1) Sampel yang digunakan dalam penelitian ini hanya 4 (empat) perusahaan. Karena hanya terdapat empat perusahaan industri rokok yang terdaftar di Bursa Efek Indonesia yang dilakukan selama periode 2016-2018; dan (2) Penelitian ini hanya mengambil jangka waktu 3 tahun yaitu tahun 2016 sampai dengan 2018, sehingga data yang diambil ada kemungkinan kurang mencerminkan kondisi perusahaan dalam jangka waktu panjang.

Saran

Adapun saran yang bisa diberikan antara lain: (1) Manajer perusahaan dalam melakukan pengambilan keputusan menaikkan profitabilitas ,hendaknya memperhatikan faktor leverage dan petumbuhan penjualan karena meskipun dianggap sebagai faktor yang bisa menaikkan profitabilitas ternyata dalam kondisi tertentu kenaikan 2 variabel tersebut tidak berpengaruh terhadap kenaikan profitabilitas; (2) Peneliti selanjutnya diharapkan dapat menggunakan periode penelitian yang lebih panjang karena semakin panjang waktu pengamatan maka semakin besar kesempatan untuk melakukan pengamatan yang lebih akurat.

\section{DAFTAR PUSTAKA}

Al Ghusin. 2015. The Impact of Financial Leverage, Growth, and Size on Profitability of Jordanian Industrial Listed Companie.( Department of Finance, Al-Zaytoonah University of Jordan).

Barus. 2013."Analisis Faktor-Faktor Yang Mempengaruhi Profitabilitas Pada Perusahaan Manufaktur Yang Terdaftar di Bursa Efek Indonesia”. (STIE Mikroskil)

Bursa Efek Indonesia 2019, Laporan Keuangan dan Tahunan, diakses pada 9 Desember 2019 dari http://www.idx.co.id/

Dwi Kartikasari.2016."The Effect of Laverage and Firm Size to Profitability of Public Manufacturing Companies in Indonesia"(Department of Management and Business).

Dewinta. 2016."Pengaruh Ukuran Perusahaan, Umur Perusahaan, Profitabilitas, Leverage dan Pertumbuhnan Penjualan Terhadap Tax Avoidance".(Jurnal Akuntansi Universitas Udayana).

Gatsi, J. G., Gadzo, S. G., dan Akoto, R. K. 2013. Degree of Financial and Operating Leverage and Profitability of Insurance Firms in Ghana. Journal of International Business and Management

Ichwan, F. Y. and Widyawati, D. (2015) 'Pengaruh Ukuran Perusahaan, Struktur Aktiva dan Profitabilitas Terhadap Struktur Modal', 4(6), pp. 1-19.

Kumalasari, R. 2016. Pengaruh Operating Leverage Dan Financial Leverage Terhadap Profitabilitas Pada Perusahaan Telekomunikasi. Jurnal Ilmu dan Riset Manajemen

Rio Kartika Supriyatna."Pengaruh Pertumbuhan Penjualan dan Likuiditas Terhadap Profitabilitas (Pada Perusahaan Consumer Goods Yang Terdaftar Pada BEI Tahun 2006-2011)(Program Pascasarjana UIKA Bogor).

Rudangga. 2016. "Pengaruh Ukuran Perusahaan, Laverage, dan Profitabilitas Terhadap Nilai Perusahaan”.(Universitas Udayana (Ubud) Bali)

Sari. 2014. "Pengaruh Pertumbuhan Perusahaan dan Laverage Terhadap Profitabilitas Dan Nilai Perusahaan”.(Universitas Udayana (Ubud) Bali) 


\section{Buletin Ekonomi}

Yulita M Gunde. 2017."Analisis Pengaruh Laverage Terhadap Profitabilitas Pada Perusahaan Manufaktur Sub Industri Food and Baverage yang Terdaftar di BEI Periode 2012-2015 (Universitas Sam Ratulangi) 


\section{Lampiran}

Penelitian Terdahulu

Tabel Penelitian Terdahulu

\begin{tabular}{|c|c|c|c|c|}
\hline $\begin{array}{l}\text { Peneliti/ } \\
\text { Tahun }\end{array}$ & $\begin{array}{c}\text { Judul } \\
\text { Penelitian }\end{array}$ & $\begin{array}{l}\text { Variabel } \\
\text { Penelitian }\end{array}$ & $\begin{array}{c}\text { Teknik } \\
\text { Analisis } \\
\text { Data } \\
\end{array}$ & Hasil Penelitian \\
\hline $\begin{array}{l}\text { Ratnasari } \\
(2016)\end{array}$ & $\begin{array}{l}\text { Pengaruh } \\
\text { Leverage, } \\
\text { Likuiditas, } \\
\text { Ukuran } \\
\text { Perusahaan } \\
\text { Terhadap } \\
\text { Profitabilitas Pada } \\
\text { Perusahaan } \\
\text { Otomotif Di BEI }\end{array}$ & $\begin{array}{l}\text { Dependen: } \\
\text { Profitabilitas } \\
\text { (Return On } \\
\text { Asset) } \\
\text { Independen: } \\
\text { 1. Leverage } \\
\text { 2. Likuiditas } \\
\text { 3. Ukuran } \\
\text { Perusahaan }\end{array}$ & $\begin{array}{l}\text { Analisis } \\
\text { Regresi } \\
\text { Linear }\end{array}$ & 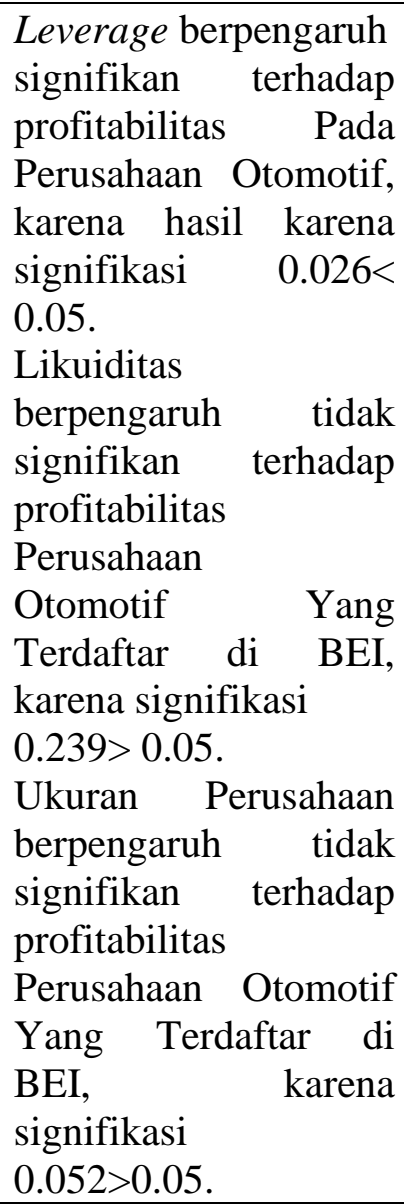 \\
\hline $\begin{array}{l}\text { Purba dan } \\
\text { Yadnya } \\
(2015)\end{array}$ & $\begin{array}{l}\text { Pengaruh Ukuran } \\
\text { Perusahaan } \\
\text { Dan Leverage } \\
\text { Terhadap } \\
\text { Profitabilitas Dan } \\
\text { Pengungk } \\
\text { apan Corporate } \\
\text { Social } \\
\text { Responsibility }\end{array}$ & $\begin{array}{l}\text { Dependen: } \\
\text { 1. Profitabilitas } \\
\text { (Return on } \\
\text { Equity) } \\
\text { 2. Corporate } \\
\text { Social } \\
\text { Responsibility } \\
\text { Independen: } \\
\text { 1. Ukuran } \\
\text { Perusahaan } \\
\text { 2. Leverage }\end{array}$ & $\begin{array}{l}\text { Analisis } \\
\text { Jalur }\end{array}$ & 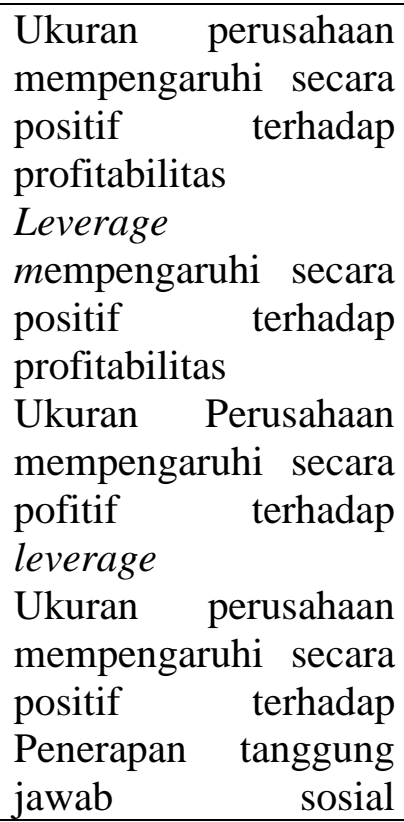 \\
\hline
\end{tabular}




\section{Buletin Ekonomi}

perusahaan.

Leverage

mempengaruhi secara

positif terhadap

pengungkapan CSR

perusahaan

\begin{tabular}{|c|c|c|c|c|}
\hline $\begin{array}{l}\text { Saridan } \\
\text { Abundanti } \\
(2014)\end{array}$ & $\begin{array}{l}\text { Pengaruh } \\
\text { Pertumbuhan } \\
\text { Perusahaan Dan } \\
\text { Leverage } \\
\text { Terhadap } \\
\text { Profitabilitas } \\
\text { Dan Nilai } \\
\text { Perusahaan }\end{array}$ & $\begin{array}{l}\text { Dependen: } \\
\text { Profitabilitas } \\
\text { (Return On } \\
\text { Asset ) } \\
\text { Nilai } \\
\text { Perusahaan } \\
\text { Independen: } \\
\text { Pertumbuhan } \\
\text { Perusahaan } \\
\therefore \text { Leverage }\end{array}$ & $\begin{array}{l}\text { Analisis } \\
\text { Jalur }\end{array}$ & 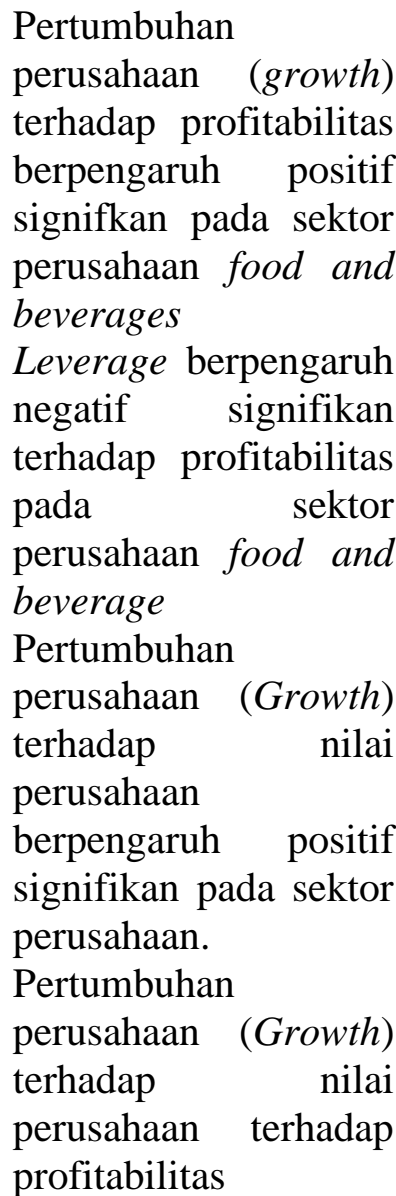 \\
\hline
\end{tabular}

